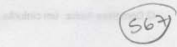

\title{
O COMPLEXO ATUBA: UM CINTURÃO PALEOPROTEROZÓICO INTENSAMENTE RETRABALHADO NO NEOPROTEROZÓICO
}

\author{
O.Siga Júnior', M.A.S.Basei', J.M.Reis Neto' ${ }^{2}$, A.Machiavelli', O.M.Harara'
}

PALAVRAS-CHAVE: Complexo Atuba, tectônica, Paleoproterozóico e Neoproterozóico.

SIGA JÚNIOR, O. et al. (1995) O Complexo Atuba: um cinturão paleoproterozóico intensamente retrabalhado no Neoproterozóico. Bol.IG-LSP, Sér. Cient. 26:69-98.

\section{RESUMO}

Os estudos realizados nos terrenos localizados entre os Cinturōes Ribeira (N) e Dom Feliciano (S) permitiram caracterizar a existência de três dominios geotectónicos com evoluçðes próprias e distintas: Domínios Luis Alves, Curitiba e Paranaguá.

O Complexo Atuba se insere no âmbito do Domínio Curitiba, que se limita a noroeste com as sequiências metassedimentares dos Gupos Açungui e Setuva, e a sudeste com os gnaisses granulíticos do Domínio Luis Alves, contatos esses que se fazem por importantes zonas de cisalhamento. Predominam no Domínio Curitiba rochas gnáissicas bandadas, migmatíticas, do fácies anfibolito, representadas principalmente por biotita-anfibólio-gnaisses contendo leucossomas de composięóes tonalitogranodioriticas além de graniticas, que compōem o aqui denominado Complexo Atuba. Caracteriza-se por migmatitos formados no Paleoproterozóico $(2.000 \pm 200 \mathrm{Ma})$, remigmatizados no Neoproterozóico $(600 \pm$ $20 \mathrm{Ma}$ ), periodo esse em que as isotermas atingiram temperaturas superiores a $500^{\circ} \mathrm{C}$. O padrão estrutural observado é indicativo de uma tectônica controlada em grande parte por cisalhamento, com importante componente lateral, e transporte relativo em direçăo a sul-sudeste.

As rochas pertencentes ao Complexo Atuba representam terrenos relativamente profundos, do fácies anfibolito, migmatizados, granitizados acrescidos à borda do Domínio Luis Alves (Microplaca Luis Alves) đurante o Neoproterozóico. Este quadro tectónico definido no final do Neoproterozóico com continuidade até o Cambro-Ordoviciano, parece ser o resultado de processos maiores, envolvendo aglutinaçōes de massas continentais, que culminaram com a formaçăo do Gondwana Ocidental.

\section{ABSTRACT}

Studies of terranes between the northem Ribeira and southern Dom Feliciano Belts allow the characterization of three geotectonic domains with different evolutions: the Luís Alves, Curitiba and Paranaguá terranes.

The Atuba Complex occurs in the Curitiba Domain, which has a northwestern limit with metassediments of the Açungui and Setuva Groups and a southwestern limit with the granulitic gneisses of the Luis Alves domains. The contacts are expressive shear zones. The predominant rocks of the Curitiba Domain are banded, migmatitic gneisses in amphibolite grade with biotite-amphibole gneissic mesosomes and tonalitic/granodioritic to granitic leucosomes, here called the Atuba Complex. The migmatites are Paleoproterozoic (2.000 $\pm 200 \mathrm{Ma}$ ) and remigmatized in Neoproterozoic ( $600 \pm 20 \mathrm{Ma}$ ). During the latter period temperatures reached more than $500^{\circ} \mathrm{C}$. The structural pattern indicated shear-controlled

\footnotetext{
'Departamento de Geologia Geral, Instituto de Geociências/USP, Säo Paulo, Brasil.

${ }^{2}$ Departamento de Geologia, Centro Politécnico/UFPR, Curitiba, Paraná.
} 
tectonics with an important lateral component, and low-angle, south-southeastwards transport direction.

The terranes of the Atuba Complex appear to represent deep-level rocks which were migmatized, granitized and then added to the border of the Luis Alves Microplate during the Neoproterozoic. This late Neoproterozoic tectonic scheme which continued to the Cambro-Ordoviciano seems to be the result of larger-scale processes of continental agglutination which ended with the formation of western Gondwanaland.

\section{INTRODUÇÃO}

Estudos recentes realizados no setor nordeste de Santa Catarina e sudeste do Paraná, em terrenos localizados entre os Cinturões Ribeira (N) e Dom Feliciano $(\mathrm{S})$, permitiram caracterizar a existência de três compartimentos geotectônicos com evoluçỗes próprias e distintas: Dominio Luís Alves, Dominio Curitiba e Domínio Paranaguá (Basei et al., 1992; Siga Jr., 1995). Ocorrem ainda, no âmbito desses domínios, expressiva granitogênese de natureza alcalina-peralcalina, bem como, importante vulcanismo ácido a intermediário relacionados a regimes distensionais pós-orogênicos (Siga Jr. et al., 1994; Siga Jr., 1995). O esboço geotectônico mostrado na Figura 1 apresenta uma visāo geral destes terrenos, que ocupam uma área superior a $16.000 \mathrm{~km}^{2}$.

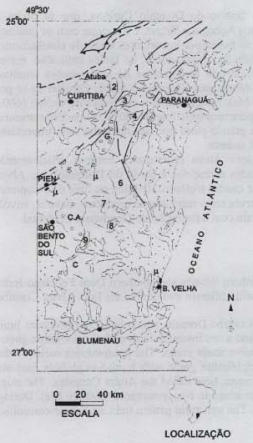

\section{LESENDA}

Depósitos cenozólcos e cobertura paleozólca da Bacia do Para-

Unidades litologicas atribuidas aos Grupos Açuncui e Setura (Cintura Ribeira - a norte) e aos Grupos Itajai e Brusque (Cin(Cinturao Ribeira - a norte)
turao Dom Feliciano - a su)

Magmatismo e sedimentaçào de tegimes axtensionais pós-orogêricos

Bacias vulcano-sedimentares: CA - Campo Alegre, $Q$ - Guara: tubinha, C-Corupá

Granitbides alcelinos-peralcalincs: 1-Graciosa, 2 - Anhangava

13 -Marumbi, 4-Serra da Igreja, 5 - Agudos do Sul, 6 -Morro Redondo, 7. Dona Francisca, 8 - Piral, 9 -Corupa

Dominio Tectônico Paranogud

_. Granitoides (Morro ingles, Rio do Poco, Canavieiras, Estrela), gnaisses, migmatitos e xistos

Dominio Tectenice Curitiba

Suite Rio Pieñ graritoides calleic-aicalinos potássices deformaTos

Complexo Atuba: gnaisses bandados, migmat tos e anfibolitos

Dominio Tectconico Luis Alves

W. Ortognaisses granulticos com intercalaçces de corpo mafico-ultramáficos $(\mu)$, quartzitos, formacoes ferriferas, paragnaisses

Figura 1 - Compartimentação tectônica da porçâo sudeste do Paraná e nordeste de Santa Catarina.

O Domínio Luís Alves limita-se, na porção setentrional, com os gnaisses 
migmatíticos e granitóides do Domínio Curitiba, no setor oriental, em parte atinge a costa brasileira e em parte é balizado pelo Domínio Paranaguá, na porção meridional, faz contato com o Cinturão Dom Feliciano, sendo a oeste recoberto pelos sedimentos da Bacia do Paraná. Os estudos realizados permitiram caracterizar a continuidade deste segmento para nordeste, rumo a Serra Negra, onde ocorre como uma estreita faixa, localizada entre os Domínios $\mathrm{Cu}$ ritiba e Paranaguá.

Litologicamente, o Domínio Luís Alves é representado por ortognaisses granulíticos, bandados a maciços, de composição tonalito-granodiorítica, com freqüentes intercalaçôes de granulitos básicos. Ocorrem, adicionalmente, ultramafitos, quartzitos, gnaisses kinzigíticos, formações ferríferas e migmatitos. O pađrão geocronológico (Basei, 1985; Siga Jr., 1995) caracteriza a presença de terrenos formados no Arqueano (2.800-2.600 Ma) e no Paleoproterozóico (2.200-1.900 Ma). Grande parte desses terrenos encontravam-se relativamente frios no Neoproterozóico, temperaturas inferiores a $300-250^{\circ} \mathrm{C}$, representando possivelmente nessa época um segmento continental (microcontinente) posicionado entre os crátons do Congo/ São Francisco-Kalahari/Paraná.

O Domínio Paranaguá ocupa grande parte da porção oriental estudada, sendo representado por granitóides heterogeneamente deformados, migmatitos, bem como por granitóides isótropos, gerados no Neoproterozóico (denominados por Lopes, 1987 de: Morro Inglês, Canavieiras, Rio do Poço e Estrela). Como restos de rochas encaixantes ocorrem xistos aluminosos, biotita gnaisses, mica xistos, quartzitos e anfibolitos. Faixas miloníticas espessas são freqüentes em meio aos granitóides tipo Morro Inglês e Canavieiras. Os limites destes terrenos com o Dominio Luís Alves são representados por expressivas zonas de cisalhamento (Lineamento do Rio Palmital, Alexandra e Serra Negra). Os dados geocronológicos (Basei et al., 1990; Siga Jr., 1995) sugerem a formação/deformação desses granitóides principalmente no intervalo $620-570 \mathrm{Ma}$. O padrão $\mathrm{K}-\mathrm{Ar}$ ( $560-480 \mathrm{Ma}$ ) indica que o resfriamento deste segmento, ou de parte dele, atingiu o Cambro-Ordoviciano, evidenciando provavelmente processos relacionados às fases finais de aglutinação das massas cratônicas e conseqüente formação do Gondwana Ocidental.

O Domínio Curitiba ocupa a porção setentrional estudada, constituindo uma faixa relativamente estreita (extensões médias da ordem de 50 a 60 $\mathrm{km}$ ) e alongada segundo a direçâo NESW. Limita-se no setor noroeste com as seqüências metassedimentares dos Grupos Açungui e Setuva e, a sudeste com os gnaisses granulíticos do Dominio Luís Alves, contatos esses que se fazem por importantes zonas de cisalhamento (Fig. 1).

O Dominio Curitiba inclui dois expressivos conjuntos de rochas, o primeiro, predominante, é representado por gnaisses bandados migmatíticos, com freqüentes intercalações de corpos anfibolíticos e de xistos magnesianos. Este conjunto, tipificado na Pedreira de Atuba (arredores de Curitiba), é aqui denominado de Complexo Atuba. O segundo conjunto é representado por granitóides cálcio-alcalinos, heterogeneamente deformados (Suite Rio Piên, Machiavelli et al., 1993), distribuídos na borda meridional do Domínio Curitiba.

Pretende-se neste trabalho abordar aspectos geológicos e, principalmente, geocronológicos do Complexo Atuba, numa tentativa de melhor posicionar esses terrenos no quadro tectônico da região. Em termos geocronológicos são disponiveis, atualmente, para esse complexo, mais de 100 determinações isotópicas utilizando-se dos métodos $\mathrm{K}-\mathrm{Ar}$, Rb-Sr, Sm-Nd e U-Pb (Siga Jr., 1995). 


\section{EVOLUÇĀO DOS CONHECIMEN- TOS}

Os trabalhos pioneiros relativos ao setor sudeste paranaense enfocam, de modo geral, um domínio gnáissico de alto grau metamórfico, de idade arqueana, considerado mais antigo que o domínio dos epimetamorfitos do Grupo Açungui, tidos como do Algonquiano. Dentre essas contribuiçôes destacam-se as de Branner (1919), Oliveira (1925, 1927), Carvalho (1936), Barbosa (1940), Oliveira \& Leonardos (1943), Abreu (1945) e Maack (1953, 1961).

Informaçø̃es mais detalhadas foram obtidas, na década de 60 , através do programa de levantamento geológico efetuado pela Comissão da Carta Geológica do Paraná, responsável pelo acervo cartográfico de grande parte do estado, nas escalas, 1:50.000, 1:70.000 e 1:75.000. Dentre os trabalhos publicados, fruto desse mapeamento, destacamse para a área estudada os de Bigarella (1965), Muratori (1966), Lopes (1966), Fuck (1966), Fuck et al. (1967a, b, c), Cordani \& Girardi (1967), Marini (1967) e Trein (1967).

$\mathrm{Na}$ uniformização adotada para a legenda dos mapas produzidos pela Comissão da Carta, foi adotada a denominação de migmatitos proposta por Jung \& Roques (1952), que implicou no agrupamento das rochas metamórficas regionais em dois conjuntos principais: migmatitos heterogêneos e migmatitos homogêneos. A primeira denominação caracterizou as rochas bandadas, que alternavam faixas de anfibolitos, biotitaxistos e quartzitos com bandas de composição granítica (destacam-se nas cartas os epibolitos), e a segunda foi aplicada principalmente a gnaisses grosseiros de aspecto granitóide (destacando-se nos mapas os embrechitos).

$\mathrm{Na}$ década de 70 merece destaque o programa de mapeamento e integraçāo geológica realizado pela CPRM, envol- vendo os projetos Leste de Santa Catarina $(1: 250.000)$ e Leste do Paraná (1:50.000 e 1:100.000). No Paraná, foram cartografadas na escala $1: 50.000$ as folhas Barra do Rio Pitangui, Ponta Grossa e Palmeira e, na escala $1: 100.000$, as folhas Piraí do Sul, Campo Largo, Cêrro Azul, Curitiba, Apiai e Guaraqueçaba, sendo utilizada para as rochas granito-gnássicas regionais, similarmente à Carta Geológica, a nomenclatura de migmatitos.

Em termos geotectônicos, Hasui et al. (1975) propõem uma compartimentação para o domínio Costeiro brasileiro, enquadrando os terrenos, ora em estudo, no Maciço Mediano de Joinville.

Com base em novos dados radiométricos, Teixeira $(1979,1982)$ apresenta uma compartimentação geocronológica no âmbito das Folhas ao Milionésimo Assunción, Curitiba e Iguape. Reconhece uma província antiga, prébrasiliana, representada pelos gnaisses granulíticos do setor NE de Santa Catarina, bem como porçōes gnáissicas afetadas pela orogênese brasiliana.

Kaul \& Teixeira (1982) apresentam uma sintese dos conhecimentos geológico-geocronológicos do setor nordeste de Santa Catarina e sudeste do $\mathrm{Pa}$ raná, limitando o Cráton Luís Alves pelos lineamentos de Corupá e de Guaruva, Os terrenos localizados a sul de $\mathrm{Cu}$ ritiba e na porção costeira săo referidos como pertencentes ao embasamento retrabalhado e rejuvenescido, incluídos por Kaul et al. (1984) no Complexo Paraiba do Sul.

Uma compartimentação interna dos terrenos localizados no setor nordeste de Santa Catarina e sudeste do $\mathrm{Pa}$ raná, em duas unidades maiores, denominadas Maciço Marginal de Curitiba e Cráton Rio de La Plata é sugerida por Basei (1985).

Merecem destaque os trabalhos de mapeamento geológico executados pelo 
Departamento de Geologia da Universidade Federal do Paraná (Curso de Graduação: 1987-1988) nos arredores de Piên. Os mapas obtidos, na escala $1: 25.000$, identificaram os granitóides deformados que ocorrem nesse setor, permitindo uma separação faciológica dos mesmos.

Com base em dados gravimétricos, Mantovani et al. (1989) apresentam um modelamento abrangendo o Cinturāo Dom Feliciano, o Cráton Luís Alves, em Santa Catarina, e o Maciço de Curitiba, no Paraná. O padrăo obtido permitiu a diferenciação dessas três unidades crustais, indicando forte anomalia positiva entre as regiōes de Agudos do Sul e Jaraguá do Sul, atribuída ao soerguimento de segmentos de crosta inferior durante os processos de justaposição dessas unidades.

Biondi et al. (1989) publicam o Mapa Geológico do Estado do Paraná $(1: 650.000)$ reunindo e reinterpretando as informações até então disponíveis. Neste mapa, a região em estudo é, sob o ponto de vista geotectônico, enquadrada no Bloco Costeiro.

Com base em dados geológicoestruturais e geocronológicos, Siga Jr. et al. $(1990 \mathrm{a}, \mathrm{b})$ identificam no setor NE de Santa Catarina e SE de Paraná, três domínios geotectônicos distintos: $\mathrm{Me}$ ridional (representado principalmente por ortogranulitos quartzo-feldspáticos); Setentrional (representado por rochas granito-gnáissicas e migmatíticas) e Costeiro (representado, principalmente, por granitóides porfiríticos).

Basei et al. (1990b, c) denominam os terrenos granito-gnáissicos e migmatíticos, da porção setentrional do $\mathrm{Ma}-$ ciço de Joinville de Nappe Rio Iguaçu. Interpretam esses terrenos como representantes da infra-estrutura do Cinturão Ribeira (Setuva e Açungui) que teriam sido lançados sobre os terrenos mais antigos, granulfticos, pertencentes ao Cráton Luís Alves. Caracterizam para esses terrenos vergência para sul e sugerem a possibilidade dos corpos básico-ultrabásicos que ocorrem nos arredores de Piên representarem restos de material oceânico obductado.

Através de dados geológico-estruturais, geoquímicos e geocronológicos, Machiavelli et al. (1991) propõem que os granitóides, deformados que ocorrem nos arredores de Piên, representem um arco vulcânico maturo, formado no Proterozóico Superior. Apresenta um mapa geológico, na escala 1:100.000, bem como novos dados geoquímicos, geocronológicos e estruturais, envolvendo os granitóides deformados, as rochas básicas e ultrabásicas, os gnaisses granuliticos e parte do corpo granítico de Agudos do Sul.

Sob o ponto de vista geotectônico, Fragoso César (1991) correlaciona o dominio gnáissico-migmatítico localizado a norte de Piên com parte dos Blocos São Gabriel e Taquarembó no Rio Grande do Sul, incluindo esses terrenos no Cinturão Ribeira. Admite evolucão similar entre os Cinturões Dom Feliciano em Santa Catarina e no Rio Grande do Sul.

Basei et al. (1992) sugerem, para - setor NE de Santa Catarina e SE do Paraná, o abandono do termo Maciço de Joinville, propondo a existência de três compartimentos geotectônicos distintos, representados pelas microplacas Curitiba e Luís Alves e pelo Cinturão Granitóide Costeiro. Neste trabalho os terrenos granulíticos representantes da Microplaca Luís Alves estendem-se para nordeste, envolvendo o Maciço Serra Negra. Admitem uma evolução para essas três unidades geotectônicas envolvendo processos de subducção seguidos de colisões, durante o Proterozóico Superior, com sentido predominantemente de acresção de E para W.

Uma compartimentação geotectônica do setor NE de Santa Catarina e SE do Paraná é apresentada por Siga Jr. 
(1995). Nesse trabalho, propōe que o Domínio Luis Alves represente um segmento continental antigo, preservado da tectônica Neoproterozóica, que afeta o Domínio Curitiba, interpretado como relacionado à borda do Cráton de Luís Alves, intensamente deformada, migmatizada e granitizada nesse periodo. A justaposição do Domínio Paranaguá terse-ia dado pouco tardiamente à evolução dos demais setores.

Harara (1996), com base em novos dados estruturais, petrológicos e geoquímicos envolvendo a região de Piên, enquadra tal setor num contexto de margem continental ativa, cenário geotectônico do Ciclo Brasiliano.

A abordagem realizada revela a existência de inúmeras propostas de modelamento geológico, envolvendo parcial ou totalmente a região estudada, caracterizadas pelas diversas denominações de cunho geotectônico. A evolução desses terrenos parece refletir a interação de entidades tectônicas distintas, através de subducções seguidas de colisōes continentais, com sentido predominante de acresção de leste para oeste. Tais compartimentos tectônicos encontram-se representados pelos Domínios Luis Alves, Paranaguá e Curitiba, sendo este último, ou grande parte dele (Complexo Atuba), o objeto principal deste trabalho.

\section{SINTESE GEOLÓGICA}

Os metassedimentos pertencentes ao Grupo Açungui, que se distribuem na porção noroeste, fora dos limites da região estudada, mostram-se afetados por importantes zonas de cisalhamento, orientadas segundo direçōes NE-SW e com transporte relativo de NW para SE (Fiori, 1992). Esta tectônica coloca as rochas do Grupo Açungui sobre as sequências essencialmente ortognáissicas do Complexo Gnaissico-Migmatítico Atuba, onde também se encontra impressa uma forte foliação milonítica orientada segundo NE-SW.

Esse contato é balizado nas proximidades de Curitiba (W-NW) por rochas graníticas hololeucocráticas, que afloram em uma faixa que se estende por mais de $20 \mathrm{~km}$ de comprimento, tendo de 5 a $10 \mathrm{~km}$ de largura. Trata-se de rochas que afloram quase sempre alteradas, de granulação média a grossa, tonalidades branco-rosadas, quartzofeldspáticas, e que se apresentam fortemente foliadas.

Nesta porção setentrional, arredores de Campo Largo, estendendo-se rumo a Colombo, ocorrem corpos de dimensões desconhecidas, representados por rochas gnáissico-granuliticas, de granulação média, com tonalidades cinza-esverdeadas e composiçōes variando de mangeriticas a noríticas (Perrota \& Morais, 1992). Apresentam texturas granoblásticas, por vezes protomiloniticas, contendo em maior ou menor proporção plagioclásio (andesina-labradorita), K-feldspato (microclínio), quartzo, hornblenda (verde-oliva), piroxênios (diopsidio e hiperstênio) e granada. A foliação é definida por forte estiramento e achatamento mineral.

De Curitiba para sudeste ocorrem gnaisses bandados, migmatíticos, normalmente com estruturas estromáticas, a mesossoma de biotita anfibólio gnaisses e leucossoma de composição tonalitogranodioritica. Essas rochas predominam no âmbito do Dominio Curitiba, distribuindo-se a sudeste de Bocaiúva do Sul, Quatro Barras e São José dos Pinhais, estendendo-se como uma faixa relativamente contínua para sudoeste, arredores de Mandirituba.

Os gnaisses bandados são normalmente leucocráticos, com termos mesocráticos, de granulaçảo média e texturas granonematoblásticas, granolepidoblásticas e por vezes, granoblásticas. São freqüentes intercalações de corpos anfibolíticos, por vezes granatíferos, 
bem como de xistos magnesianos, cujas dimensōes e formas mostram-se variadas, ocorrendo desde lentes centimétricas intercaladas nos gnaisses a corpos métricos, podendo se constituir na litologia predominante.

São comuns feições relacionadas a uma segunda fase de migmatização, cujos mobilizados brancos, por vezes róseos, de granulação fina a média, até muito grossa, mostram-se normalmente concordantes com o bandamento gnáissico. Esses mobilizados, cujas bandas apresentam normalmente dimensōes centimétricas a métricas, mostram-se ri$\cos$ em quartzo e feldspatos, apresentando muitas vezes composições graniticas a granodioríticas (Fotos A e B).

Os litotipos descritos, incluidos no Complexo Atuba, encontram-se balizados no setor meridional do Domínio Curitiba por granitóides heterogeneamente deformados (Fig. 1). Representa um conjunto de rochas, denominadas por Machiavelli et al. (1993) de Suite
Granítica Rio Piên. Apresentam granulação média a grossa, são em geral leucocráticos, de cor cinza-rosada, apresentando de maneira esparsa megacristais de feldspatos brancos e/ou rosados. Esses granitóides foram interpretados como pertencentes a raizes de um provável arco magmático do Proterozóico Superior (Machiavelli et al., 1991, 1993; Machiavelli, 1991; Basei et al., 1992; Harara, 1996).

De maneira bastante sucinta, destaca-se no âmbito dos gnaisses bandados a presença de plagioclásio (albitaoligoclásio, por vezes zonado e com lamelas encurvadas), quartzo (grãos irregulares com extinção ondulante), hornblenda (pleocroismo de verde claro a verde escuro, normalmente poiquilítica), biotita (por vezes ausente, pleocroismo de marrom claro a pardo), k-feldspato (presença rara, apresentando geminação em grade, fortemente saussuritizado) e clorita (normalmente associada a biotita). Nos termos mais mesocráticos po-

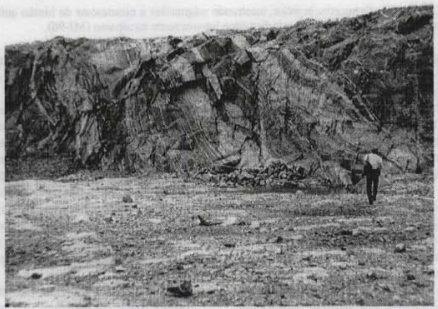

Foto A - Aspecto geral da Pedreira de Atuba, caracterizando injeçōes de granitóides leucocráticos em biotita anfibólio gnaisses migmatiticos. Nestes predominam quartzo, plagioclásio, K-feldspato, biotita e homblenda (MJ-96). 


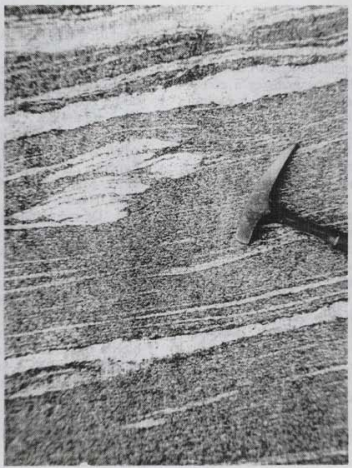

Foto B - Detalhe do afloramento anterior, mostrando migmatitos a mesossoma de biotita anfibólio gnaisses e leucossoma predominantemente trondjemítico intensamente transposto (MJ-96).

dem ocorrer, adicionalmente, hiperstênio e/ou diopsídio (relictos internos aos anfibólios) e granada. Os minerais acessórios comuns são allanita, titanita, zircão, apatita e opacos e, como produtos de alteração, epídoto e carbonato. Um retrometamorfismo em grau baixo é sugerido pela presença de clorita, zoisita e epidoto.

Geoquimicamente, foram realizadas análises em quatro amostras deste complexo: rochas gnáissico-granuliticas que ocorrem a norte de Curitiba (MJ25.3), porçōes anfibolíticas contendo granada, localizadas a norte de Mandirituba (MJ-137) e em bandas mesocráticas pertencentes aos gnaisses bandados migmatíticos (MJ-138 e MJ-96.3), a primeira localizada a norte de Mandirituba e a segunda referente à pedreira Atuba, em Curitiba.

Embora pouco representativas deste domínio, uma vez que somente quatro amostras foram analisadas, uma afinidade cálcio-alcalina pode ser grosseiramente observada em diagrama $R_{1} x$ $\mathbf{R}_{2}$ (Fig. 2). Os padrões de terras raras são fortemente fracionados e indicam na rocha gnáissico-granulítica (amostra de número de campo: MJ-25.3), distintamente das demais, anomalia positiva de Eu (Fig. 3).

Do ponto de vista estrutural, verifica-se para os litotipos pertencentes ao Complexo Atuba uma orientação predominantemente nordeste, que inclui a 


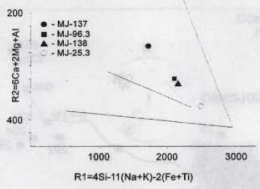

Figura 2 - Diagrama $R_{1}-R_{2}$ (De La Roche et al., 1980) - Dominio Curitiba.

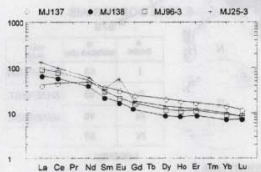

Figura 3 - Padräo de Terras Raras - Dominio Curitiba (normalizado segundo Evensen et al., 1978).

superficie $\mathrm{S}_{\mathrm{n}}$ (principal) dos leucogranitos, gnaisses granulíticos e gnaisses bandados migmatíticos. Essas superficies correspondem a uma foliação de transposição, paralela ao bandamento, cujas características sugerem uma deformação controlada principalmente por cisalhamento dúctil, com feldspatos rotacionados, forte estiramento dos anfibólios e do quartzo.

Verificam-se, na maioria das unidades deste dominio (estereogramas de 1 a 4 - Fig. 4), mergulhos relativamente fortes desta foliação $S_{n}$, com caimentos ora para NW, ora para SE.

As estruturas lineares incluem tanto lineaçôes $b$, que podem representar eixos de dobras tardias, de intersecçōes de superficies $S_{n} / S_{n+1}$, bem como lineações de estiramento do tipo a. As lineaçōes de estiramento referem-se principalmente a cristais de quartzo, feldspato, anfibólio, ou mesmo de agregados minerais, que se apresentam estirados nos planos da foliação $\mathrm{S}_{\mathrm{n}}$. Estas distribuem-se preferencialmente no quadrante NE, apresentando mergulhos relativamente baixos (Fig. 4), sugerindo uma tectônica de cisalhamento com importante componente lateral. Os indicadores cinemáticos (relações $\mathrm{S}_{\mathrm{S}} / \mathrm{S}_{\mathrm{c}}$ e feldspatos rotacionados) sugerem um transporte relativo de norte para sul.

\section{ESTUDOS GEOCRONOLÓGICOS}

A região estudada conta com mais de 100 determinações geocronológicas, envolvendo os métodos $\mathrm{K}-\mathrm{Ar}$, $\mathrm{Rb}-\mathrm{Sr}$, $\mathrm{U}-\mathrm{Pb}$ e $\mathrm{Sm}-\mathrm{Nd}$. A maioria dessas análises foi realizada nos laboratórios do Centro de Pesquisas Geocronológicas do Instituto de Geociências da Universidade de São Paulo - CPGeo/IG-USP. Dispõe-se também de análises realizadas através de cooperação cientifica com laboratórios de Kansas (EUA) e Milton Keynes (UK), especificadas no apêndice. As interpretações geocronológicas obedeceram às particularidades especificas inerentes a cada metodologia, comentadas em Siga Jr. (1995).

O estudo geocronológico de rochas pertencentes ao Complexo Atuba mostrou-se problemático, uma vez que esses terrenos são constituídos por duas gerações de migmatitos. As variáveis envolvidas nesse estudo incluem aspectos relacionados à representatividade do sistema rocha total das amostras coletadas, o grau de homogeneização isotópica entre os constituintes, bem como a gênese complexa dos mesmos. Tais fatos fizeram com que fossem realizados, sempre que possível, estudos radiométricos envolvendo além do sistema rocha total, as diferentes fases minerais 


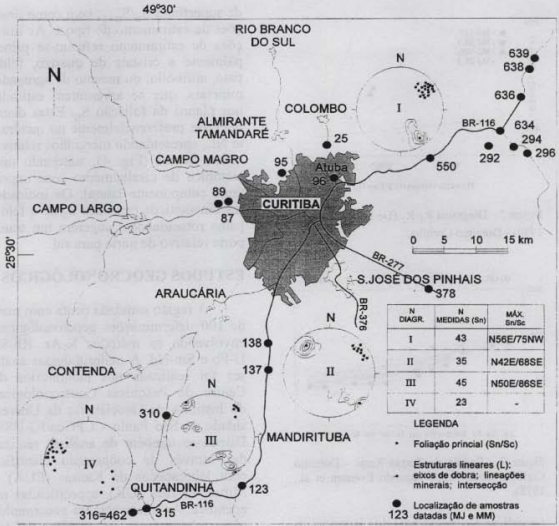

Figura 4 - Padrão estrutural do Complexo Gnáissico-Migmatítico Aruba.

presentes.

A aplicação da metodologia $\mathrm{Rb}-\mathrm{Sr}$ (rocha total) nos gnaisses granuliticos, localizados a norte de Curitiba, envolveu dezenas de amostras, coletadas em diferentes afloramentos, uma vez que as razōes $\mathrm{Rb} / \mathrm{Sr}$ mostraram-se constantemente baixas e relativamente próximas. Foram selecionadas amostras de três corpos, que apresentaram distribuição das relaçōes $\mathrm{Rb}^{87} / \mathrm{Sr}^{86}$ entre 0,3 e 1,4 . Os dados analíticos referentes às amostras do afloramento de número de campo MJ-25 mostraram certa dispersão em diagrama isocrônico, indicando idade de $1.826 \pm 96 \mathrm{Ma}$, para uma relaçăo inicial $\left(\mathrm{Sr}^{87} / \mathrm{Sr}^{86}\right)_{\mathrm{i}}$ de $0,71051 \pm 0,00383$ (Fig. 5). Os dados relativos aos corpos localizados a oeste, afloramentos de número de campo MM-87 e MM-89, apresentaram-se dispersos no diagrama isocrôni$\mathrm{co}$, denotando forte desequilibrio isotópico do sistema Rb-Sr (Fig. 5). Um alinhamento paralelo foi tentativamente traçado, envolvendo três das amostras datadas, indicando mesma idade $(\sim 1830$ $\mathrm{Ma})$ e relação inicial inferior $(\sim 0,707)$, de pouco ou nenhum significado geoló- 


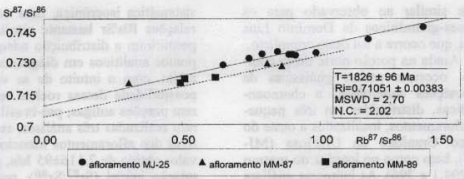

Figura 5 - Diagrama isocrónico Rb-Sr em rocha total para os Gnaisses Granuliticos localizados a norte de Curitiba:

gico.

Numa tentativa de melhor definir a idade obtida, foram realizadas dataçōes U-Pb, em três fraçôes de zircão, da amostra de número de campo MJ-25.11, relativa aos gnaisses granulíticos acima analisados. Os pontos analíticos distribuíram-se próximos a curva concórdia, indicando idade de $2.095 \pm 5 \mathrm{Ma}$, interpretada como relacionada à época de cristalização dos zircões (Fig. 6).

A ausência de biotita, aliada à pre-

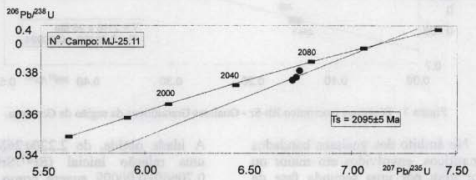

Figura 6 - Diagrama U-Pb em zircões - Gnaisses Granulíticos da Pedreira CESB - norte de Curitiba.

sença de piroxênios e anfibólios, cuja separação é impraticável, restringiu a aplicação da metodologia $\mathrm{K}$-Ar nesses gnaisses granulíticos. Uma única amostra (MM-89D), contendo quantidades significativas de anfibólios e baixa porcentagem em piroxênios, permitiu a obtenção de um concentrado com cerca de $85 \%$ de hornblenda, que indicou idade $\mathrm{K}-\mathrm{Ar}$ de $1.755 \pm 70 \mathrm{Ma}$. O elevado erro obtido para a idade deve refletir a presença de impurezas no material analisado.

Adicionalmente, realizou-se uma análise $\mathrm{Sm}-\mathrm{Nd}\left(\mathrm{T}_{\mathrm{DM}}\right)$, da amostra de número de campo $\mathrm{MJ}-25.3$, que acusou idade modelo de $2.822 \mathrm{Ma}$, interpretada como relativa a época em que os precursores crustais dessas rochas derivaramse do manto.

Pelo exposto, os dados obtidos caracterizam a formação dessas rochas no Paleoproterozóico (Ciclo Transamazônico), indicando adicionalmente que as mesmas encontravam-se relativamente frias (temperaturas inferiores a $500^{\circ} \mathrm{C}$ ) no Neoproterozóico (Ciclo Brasiliano). Este padrāo geocronológico é relativa- 
mente similar ao observado para os gnaisses-granulíticos do Domínio Luis Alves, que ocorre a sul deste complexo.

Ainda na porção norte deste complexo, ocorrem rochas gnáissicas de composiçōes enderbíticas a chamoenderbíticas, distribuídas em três pequenos afloramentos, localizados a oeste do Maciço Granítico da Graciosa (MJ292C), bem como no interior do mesmo (MJ-294.1 e 296). As inúmeras análises semi-quantitativas de $\mathrm{Rb}$ e $\mathrm{Sr}$ realizadas em amostras pertencentes a esses afloramentos restringiram a utilização da sistemática isocrônica, uma vez que as relaçōes $\mathrm{Rb} / \mathrm{Sr}$ bastante similares, não permitiram a distribuição adequada dos pontos analíticos em diagrama. Mesmo assim, com o intuito de se verificar a possibilidade dessas rochas representarem porções antigas, pré-brasilianas, foram realizadas três análises, representativas dos afloramentos mencionados. $\mathrm{O}$ valor obtido de $2.116 \pm 95 \mathrm{Ma}$, para uma relação inicial $\left(\mathrm{Sr}^{87} / \mathrm{Sr}^{86}\right)_{i}$ próxima de 0,702 (Fig. 7), sugere, de modo precário, tratar-se de rochas de idade paleoproterozóica.

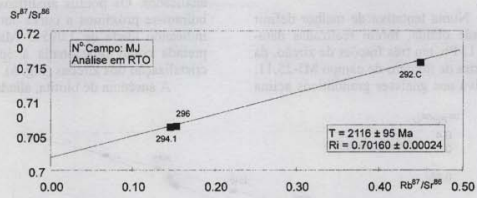

Figura 7 - Diagrama isocrônico Rb-Sr - Gnaisses Granuliticos da regiāo da Graciosa.

No âmbito dos gnaisses bandados migmatíticos, envolvidos em maior ou menor grau por uma segunda fase de migmatização, foram selecionados para estudos geocronológicos, afloramentos localizados nas proximidades de Curitiba, Mandirituba e Quitandinha.

Ao longo da BR-116, a NE de Curitiba, foram analisadas, através do método $\mathrm{Rb}-\mathrm{Sr}$ em rocha total, cinco amostras, pertencentes a três afloramentos (MJ-550, 633.A e 638.A, B, C) de biotita anfibólio gnaisses bandados de composição tonalítica. Tais amostras, apresentaram relações $\mathrm{Rb}^{87} / \mathrm{Sr}^{86}$ relativamente baixas e próximas entre si, denotando em diagrama isocrônico uma forte dispersão dos pontos analíticos, refletido no elevado valor do MSWD.
A idade obtida, de $2.220 \pm 26 \mathrm{Ma}$ para uma relação inicial $\left(\mathrm{Sr}^{87} / \mathrm{Sr}^{86}\right)_{\mathrm{i}}$ de $0,70660 \pm 0,00009$, sugere, como no caso anterior, a formação dessas rochas no Paleoproterozóico (Ciclo Transamazônico, Fig. 8).

Análises $\mathrm{K}-\mathrm{Ar}$ realizadas $\mathrm{em}$ biotitas e anfibólios de alguns desses afloramentos (MJ-550, 638.A, 636.A e 639.1) distribuiram-se no intervalo 650 $600 \mathrm{Ma}$, indicando que essas rochas atingiram temperaturas superiores a $450-500^{\circ} \mathrm{C}$ durante o Neoproterozóico.

Ainda nas proximidades de Curitiba (Pedreira Atuba), ocorrem rochas gnáissico-migmatíticas, cujos mesossomas são predominantemente biotita anfibólio gnaisses, e os leucossomas apresentam composições tonalito-granodio- 


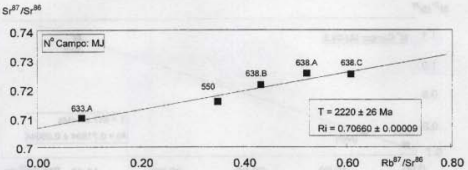

Figura 8 - Diagrama isocrônico Rb-Sr em rocha total. Biotita Anfibólio Gnaisses bandados, localizados a NE de Curitiba.

ríticas. Uma segunda fase de migmatização inclui bandas róseas, ricas em $\mathrm{K}$ feldspato, bem como, de composições granito-granodioríticas. $\mathrm{O}$ estudo geocronológico realizado através do método $\mathrm{Rb}$-Sr envolveu principalmente os migmatitos da primeira geração, sendo efetuado tanto a nivel de rocha total como de minerais. Os dados analíticos relativos ao sistema rocha total, mostraram-se bastante dispersos em diagrama isocrônico $\mathrm{Rb}-\mathrm{Sr}$, denotando forte desequilíbrio isotópico desses elementos. A reta que melhor se ajusta a esses pontos (inclui somente cinco amostras: MJ96.1, 96.3, 96.4, 96.6 e 96.8), apresentou idade de $598 \pm 48 \mathrm{Ma}$, para uma relação inicial $\left(\mathrm{Sr}^{87} / \mathrm{Sr}^{86}\right)_{\mathrm{i}}$ de $0,71650 \pm$ 0,00220 (Fig. 9). Duas análises realizadas em bandas leucossomáticas, de composiçōes graníticas, não se encontram representadas nesse diagrama por apresentarem relações $\mathrm{Rb}^{87 / \mathrm{Sr}^{86}}$ mais elevadas, posicionando-se acima da reta mencionada.

As análises $\mathrm{Rb}-\mathrm{Sr}$ em minerais

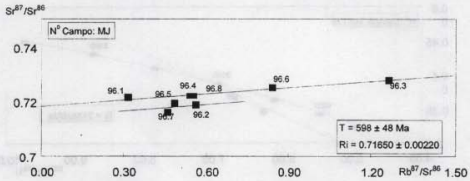

Figura 9 - Diagrama isocrônico Rb-Sr em rocha total - Migmatitos da Pedreira Atuba - Curitiba.

(biotita e anfibólio) relativas à amostra de número de campo MJ-96.3, representante dos biotita anfibólio gnaisses a leucossomas tonalito-granodioriticos, alinharam-se em diagrama isocrônico indicando idade de $617 \pm 14 \mathrm{Ma}$ para uma relação inicial $\mathrm{Sr}^{87} / \mathrm{Sr}^{86}$ próxima de 0,716 (Fig, 10). Valor relativamente próximo ( $588 \pm 27 \mathrm{Ma})$, foi obtido em biotita concentrada da rocha gnáissicomigmatítica, de número de campo $\mathrm{MJ}$ 96.9, utilizando-se do método K-Ar. Tais dados caracterizam a grande expressão da tectônica neoproterozóica 


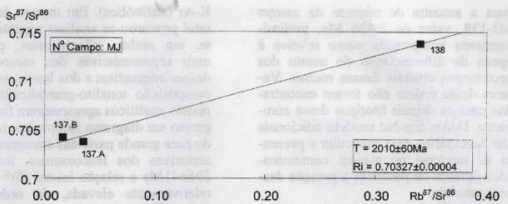

Figura 12 - Diagrama isocrônico Rb-Sr em rocha total Gnaisses dos arredores de Mandirituba.

análises adicionais para que tenha significado geológico.

Com o intuito de se determinar a época de formação da paragênese mineral desses gnaisses, foram concentrados minerais (plagioclásio, anfibólio e granada) da amostra de número de campo MJ-137 que, juntamente com o sistema rocha total, foram analisados através do método Sm-Nd. É importante salientar que o estudo petrográfico acusou a presença de restos de piroxênio (diopsídio e hiperstênio) parcial ou totalmente en- volvidos por cristais de homblenda, bem como de plagioclásios parcialmente recristalizados. Portanto, os pontos analíticos relativos ao anfibólio e ao plagioclásio podem, em realidade, conter heranças isotópicas pretéritas. No cálculo da idade foi atribuído peso menor a esses minerais, resultando na idade de $585 \pm 30 \mathrm{Ma}$ (Fig. 13), indicativa de uma rehomogeneização isotópica a nivel mineral, durante o Ciclo Brasiliano (Neoproterozóico).

Os dados K-Ar, em biotitas, acu-

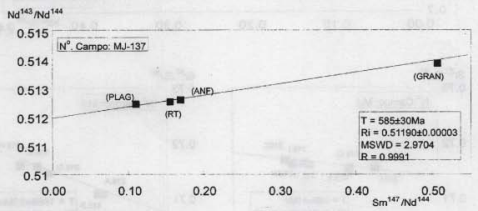

Figura 13 - Diagrama isocrônico Sm-Nd em minerais e rocha total. Anfibólio Gnaisses dos arredores de Mandirituba.

saram idades de $602+76 \mathrm{Ma}$ e $611 \pm 19$ $\mathrm{Ma}$, respectivamente para as amostras de número de campo $\mathrm{MJ}-137$ e 138 . O valor obtido para o anfibólio da amostra
$\mathrm{MJ}-138$ de $751=24 \mathrm{Ma}$ deve ser encarado com ressalvas, devido à presença de relictos de piroxênios no sistema.

A idade $\mathrm{Sm}-\mathrm{Nd}\left(\mathrm{T}_{\mathrm{DM}}\right)$ indicou, 
para a amostra de número de campo MJ-138, valor de $2.426 \mathrm{Ma}$, preliminarmente interpretada como relativa à época de diferenciação do manto dos precursores crustais dessas rochas. Valores dessa ordem não foram encontrados para os demais litotipos desse complexo. Dados Sm-Nd modelo adicionais são necessários para especular a presença de misturas ou mesmo contaminações durante ou posterior à geração desses materiais.

Ainda no contexto das rochas gnáissico-migmatíticas, dois afloramentos (MJ-315 e 316), localizados nos arredores de Quitandinha, foram estudados geocronologicamente através dos métodos $\mathrm{Rb}-\mathrm{Sr}$ (rocha total e mineral) e
$\mathrm{K}$-Ar (anfibólios). Em termos de rocha total procurou-se analisar separadamente, em ambos afloramentos, porções mais representativas dos mesossomas desses migmatitos e dos leucossomas de composiçāo tonalito-granodioritica. Os pontos analíticos apresentaram forte dispersão em diagrama isocrônico, indicando para grande parte das amostras representativas dos leucossomas, idade de $595 \pm 41 \mathrm{Ma}$ e relação inicial $\left(\mathrm{Sr}^{87} / \mathrm{Sr}^{86}\right)_{i}$ relativamente elevada, da ordem de 0,713 (Fig. 14.A). Parte das amostras representativas dos mesossomas dessas rochas gnáissico-migmatíticas sugere idade mais antiga, próxima de $1.870 \mathrm{Ma}$, para uma relação inicial $\left(\mathrm{Sr}^{87} / \mathrm{Sr}^{86}\right)_{i}$ da ordem de 0,706 (Fig. 14.B). Tal padrão
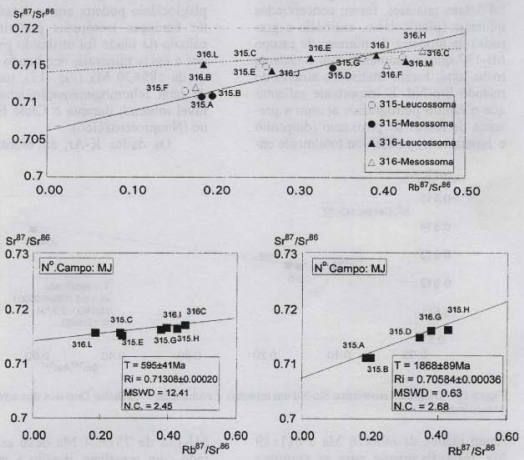

Figura 14 - Diagrama isocrônico Rb-Sr em rocha total - Gnaisses Migmatiticos dos arredores de Quitandinha. Figura 14A - Leucossomas. Figura 14B - Mesossomas. 
indica um forte desequilibrio isotópico, reflexo da tectônica Neoproterozóica, responsável pela remigmatização de rochas formadas em épocas anteriores, relacionadas ao Paleoproterozóico.

Análises $\mathrm{Rb}-\mathrm{Sr}$ realizadas em minerais (feldspato, biotita e anfibólio) de mobilizados granítico-granodioríticos, indicaram em diagrama isocrônico ida- de de $577 \pm 17 \mathrm{Ma}$ (Fig. 15). Valores relativamente similares foram obtidos, através do método $\mathrm{K}-\mathrm{Ar}$, em anfibólios desses afloramentos ( $568 \pm 33 \mathrm{Ma}$ e $593 \pm$ $16 \mathrm{Ma})$ e em biotita (566 $\pm 15 \mathrm{Ma}) \mathrm{de}$ outro afloramento relativamente próximo (MJ-310), concentrados de porções gnáissico-migmatíticas de composiçōes tonalito-granodioríticas.

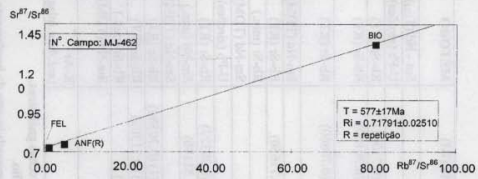

Figura 15 - Diagrama isocrônico Rb-Sr em minerais de mobilizados de rochas Graniticas e Gnáissico Migmatíticas dos arredores de Quitandinha.

Finalmente, vale acrescentar que os granitóides deformados de composição predominantemente monzogranitica a quartzo-monzodiorítica, que balizam a porção sul do Complexo Atuba apresentam idade de formação de $615 \pm 30 \mathrm{Ma}$ (U-Pb em zircões; Siga Jr., 1995) e de resfriamento no intervalo $620-560 \mathrm{Ma}$ (Machiavelli, 1991; Siga Jr., 1995). As idades $\mathrm{Sm}-\mathrm{Nd}\left(\mathrm{T}_{\mathrm{DM}}\right)$ distribuem-se entre 2.100-2.000 Ma (Siga Jr., 1995) diferindo das observadas para grande parte das rochas pertencentes ao Complexo Atuba $(2.800-2.700 \mathrm{Ma})$, aproximandose do valor observado para os mobilizados graníticos do afloramento de número de campo MJ-123 (2.275 Ma). Tais valores indicam o Paleoproterozóico como principal periodo de diferenciaçāo do manto dos precursores crustais dessas rochas graníticas.

\section{CONSIDERAÇÕES FINAIS}

O Complexo Atuba, integrante do
Domínio Curitiba, mostra características geológicas, geocronológicas e estruturais distintas dos terrenos adjacentes, pertencentes aos Domínios Luís Alves e Paranaguá. Seus limites såo representados por expressivas zonas de cisalhamento, marcadas na porção sul por importantes anomalias gravimétricas negativas.

O padrão geocronológico observado para os litotipos do Complexo Atuba, sintetizado no Quadro 1, permite reconhecer rochas formadas no Paleoproterozóico (Ciclo Transamazônico), com idades $\mathrm{Rb}-\mathrm{Sr}$ distribuídas no intervalo 2200-1800 Ma, e U-Pb (zircōes) próximas de $2.100 \mathrm{Ma}$. No Neoproterozóico (Ciclo Brasiliano) essas seqüências foram intensamente remigmatizadas, causando a abertura dos sistemas minerais, mas preservando heranças isotópicas, do Paleoproterozóico, notadamente em zircōes. As relaçōes iniciais $\left(\mathrm{Sr}^{87} / \mathrm{Sr}^{86}\right)_{i}$ mostram-se relativamente elevadas no Neoproterozóico, sugerindo origem a partir de reservatórios crustais. 


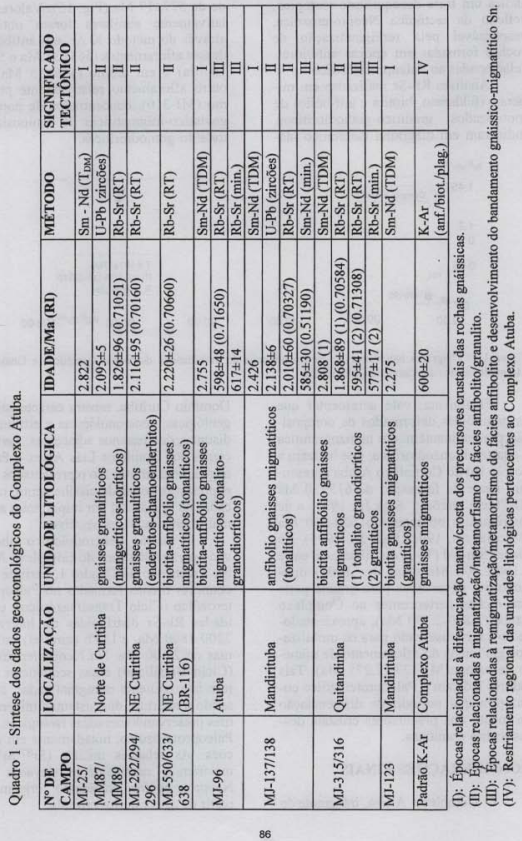


Os dados Sm-Nd indicam, à exceção do mobilizado granítico coletado no afloramento de número de campo MJ123 (que apresentou idade modelo de $2.275 \mathrm{Ma}$ ) e do anfibólio gnaisse de número de campo MJ-138 (2.426 Ma), valores do intervalo $2.800-2.700 \mathrm{Ma}$, relacionados à diferenciação do manto dos precursores crustais dessas rochas. Os valores de $\varepsilon_{\mathrm{Nd}}$ mostram-se menos negativos no Paleoproterozóico $(-1,2$ a $-6,5)$ do que no Neoproterozóico (-20 a -22$)$, sugerindo neste último caso longo periodo de residencia crustal dos protolitos dessas rochas.

O padrão geológico-estrutural, observado para as rochas pertencentes ao Complexo Atuba, indica que o desenvolvimento da foliação $\mathrm{S}_{\mathrm{n}}$ paralela ao bandamento gnáissico tenha-se processado em regimes dúcteis associados a uma tectônica controlada em grande parte por cisalhamentos com importante componente lateral. Os indicadores cinemáticos são sugestivos de um transporte relativo em direção ao Domínio Luís Alves (para SE).

Considerando-se o forte desequilibrio isotópico do sistema Rb-Sr em rocha total, os valores obtidos (ao redor de $600 \mathrm{Ma}$ ) tornam-se bastante imprecisos, dificultando a caracterização de idades relativas à formação dessas rochas em condições metamórficas do fácies anfibolito. Acrescente-se, que as idades isocrônicas de minerais distribuíram-se entre aproximadamente 620 e $580 \mathrm{Ma}$, e os dados K-Ar (anfibólio, biotita e plagioclásio) entre 640 e $560 \mathrm{Ma}$ (com maior concentração no intervalo $600 \pm 20$ $\mathrm{Ma)}$, caracterizando épocas relacionadas ao resfriamento desses terrenos. Observa-se uma tendência das isócronas $\mathrm{Rb}$ $\mathrm{Sr}(\mathrm{RT})$ relativas a rochas coletadas em afloramentos distintos apresentarem idades paleoproterozóicas, e as de mesmo afloramento, idades neoproterozóicas com forte dispersão dos pontos analíti$\cos$. Tal fato sugere uma relativa homo- geneizaçâo isotópica (em termos de $\mathrm{Rb}$ e Sr) a nivel de afloramento, no Neoproterozóico, mas nem sempre entre afloramentos distintos. Os valores em minerais, por outro lado (isócronas $\mathrm{Rb}-\mathrm{Sr}$ e dados K-Ar), mostram-se sistematicamente neoproterozóicos, indicando o período principal $(600 \pm 20 \mathrm{Ma})$ de alçamento (isotermas inferiores a 450 $500^{\circ} \mathrm{C}$ ) e consequiente resfriamento regional desses terrenos.

As características isotópicas, aliadas ao padrão geológico-estrutural, permitem associar o desenvolvimento da foliação $S_{n}$, paralela ao bandamento gnáissico migmatítico, durante $0 \mathrm{Neo}$ proterozóico. Acrescente-se que padrão estrutural bastante similar foi descrito por Fiori (1990) para os metassedimentos do Grupo Açungui, na região de Rio Branco do Sul, sugerindo um possivel desenvolvimento comum dessas estruturas nessa época.

As rochas pertencentes ao Complexo Atuba representam, portanto, terrenos relativamente profundos, do făcies anfibolito, intensamente retrabalhados, migmatizados e granitizados acrescidos à borda do Domínio Luis Alves (Microplaca Luis Alves) durante o Neoproterozóico.

O Quadro 2 apresenta uma síntese da evolução geotectônica do Complexo Atuba, com base na interpretação dos dados geológicos e geocronológicos apresentados.

\section{AGRADECIMENTOS}

Os autores desejam expressar sinceros agradecimentos à maioria dos colegas do Centro de Pesquisas Geocronológicas e do Departamento de Geologia Geral do Instituto de Geociências da USP pelas discussões, que muito contribuíram na elaboração deste trabalho. Aos revisores científicos deste texto, Profs. Drs. João C. Biondi, Márcio M. Pimentel e Wilson Teixeira, os agrade- 
Quadro 2 - Sintese da Evoluçâo Geotectônica do Complexo Atuba.

\begin{tabular}{|c|c|c|}
\hline FENÓMENO & EVIDÊNCIAS ISOTÓPICAS & IDADE (Ma) \\
\hline $\begin{array}{l}\text { Diferenciação e Acresção de } \\
\text { material do manto à crosta. }\end{array}$ & Idades Modelo Sm-Nd ( $\mathrm{T}_{\mathrm{DM}}$ ). & $2.700 \pm 100$ \\
\hline $\begin{array}{l}\text { Metamorfismo Regional do fá- } \\
\text { cies anfibolito a granulito com } \\
\text { migmatização associada. }\end{array}$ & $\begin{array}{l}\text { Dados U-Pb (zircões) e Rb-Sr (RT), } \\
\text { Valores de } \varepsilon_{\mathrm{Nd}} \text { negativos (-1.2 a - } \\
\text { 6.5). Possível adição de material } \\
\text { juvenil à crosta (idade } \mathrm{Sm}-\mathrm{Nd}-\mathrm{T}_{\mathrm{DM}} \\
\text { de bandas de composição granitica). }\end{array}$ & $2.000 \pm 200$ \\
\hline $\begin{array}{l}\text { Metamorfismo Regional do fá- } \\
\text { cies anfibolito com remigmati- } \\
\text { zação e desenvolvimento do ban- } \\
\text { damento gnáissico Sn. Consti- } \\
\text { tuição do Complexo Atuba. }\end{array}$ & $\begin{array}{l}\text { Dados isocrônicos Rb-Sr (RT) e } \\
\text { Sm-Nd (Min.). Constituiçåa do } \\
\text { Complexo Atuba. Valores de } \varepsilon_{\text {Na }} \\
\text { bastante negativos }(-20 \mathrm{a}-22) \text {. }\end{array}$ & $\begin{array}{l}\quad 600 \pm 40 \\
\text { (Desequilibrio isotó- } \\
\text { pico do sistema Rb- } \\
\text { Sr em RT - idades } \\
\text { imprecisas) }\end{array}$ \\
\hline $\begin{array}{l}\text { Estabilização Tectônica: alça- } \\
\text { mento e resfriamento regional. }\end{array}$ & $\begin{array}{l}\text { Valores K-Ar (plagioclásios, bioti- } \\
\text { tas e anfibólios) e isócronas Rb-Sr } \\
\text { em minerais. }\end{array}$ & $600 \pm 20$ \\
\hline
\end{tabular}

cimentos sinceros dos autores pelas sugestões e comentários críticos. A FAPESP que, durante o transcorrer dos estudos, concedeu-nos recursos financeiros para o desenvolvimento das pesquisas de campo, análises químicas e geocronológicas.

\section{REFERÊNCIAS BIBLIOGRÁFICAS}

ABREU, S.F. (1945) Fundamentos Geográficos da Mineração Brasileira. Revista Brasileira de Geografia, v. 7, n. 1, p. 3-137.

ALMEIDA, F.F.M. (1967) Origem e evolução da Plataforma Brasileira. Boletim Divisāo de Geologia e Mineralogia, v.241, p.1-36.

BARBOSA, O. (1940) Reservas de minérios de ferro em Santa Catarina. Mineração e Metalurgia, v.5, n.25, p.21-24.

BASEI, M.A.S. (1985) O Cinturão Dom Feliciano em Santa Catarina. São Paulo, 190p. (Tese - Doutorado) - Instituto de Geociências, Universidade de São Paulo.

BASEI, M.A.S.; SIGA Jr., O; MACHIAVELLI, A. (1990c) Tectonic relationship between the Dom Feli- ciano Belt and the Joinville Massif, Southern Brazil. In: WORKSHOP "GEOQUIIMICA ISOTÓPICA, LITO-GEOQUIMICA E GEOCRONOLOGLA DAS REGIÕES SUL E SUDESTE DO BRASIL", São Paulo. Boletim de Resumos. São Paulo, 1990. SBG, v.1, p.17-19.

BASEI, M.A.S.; SIGA Jr., O,; KAWASHITA, K. (1990d) A K-Ar profile through the Joinville Massif and the Dom Feliciano Belt, southem Brazil - tectonic implications. In: INTERNATIONAL CONFERENCE ON GEOCHRONOLOGY COSMOCHRONOLOGY AND ISOTOPE GEOLOGY, 7., Camberra, 1990. Ab-stracts. Camberra, Australia, v. 27, p. 8 .

BASEI, M.A.S.; SIGA Jr., O.; MACHIAVELLI, A.; MANCINI, F. (1991) Evolução tectônica do Maciço de Joinville (PR - SC). In: SIMPOSIO NACIONAL DE ESTUDOS TECTÔNICOS, 3., Rio Claro, 1995. Boletim de Resumos. Rio Claro, SBG, p.132-133.

BASEI, M.A.S.; SIGA Jr., O.; MACHIAVELLI, A.; MANCINI, F. (1992) Evolução tectônica dos ter- 
renos entre os Cinturões Ribeira e Dom Feliciano (PR - SC). Revista Brasileira de Geociências, v.22, n.2, p.216-221.

BASEI, M.A.S.; SIGA Jr., O.; SATO, K.; SPRÖESSER, W.M. (1995) A instalação da metodologia UrânioChumbo na Universidade de São Paulo. Princípios metodológicos, aplicações e resultados obtidos. Anais da Academia brasileira de Ciências, v. 67, n.2, p. $221-237$.

BATOLLA Jr., F.; HAMA, M.; LOPES Jr., I. (1977) Idades radiométricas $\mathrm{Rb} / \mathrm{Sr}$ e $\mathrm{K} / \mathrm{Ar}$ em rochas cristalinas pré-brasilianas da região leste do Estado do Paraná. In: SIMPÓSIO REGIONAL DE GEOLOGIA, 1., São Paulo, 1977. Atas. São Paulo, SBG, p.324-337.

BIGARELLA, J.J. (1965) Nota explicativa acompanhando a Folha Geológica de Paranaguá. Boletim da Universidade Federal do Paraná, Geologia, v.13, p.1-6.

BIONDI, J.C.; CAVA, L.T.; SOARES, P.C. (1989) Mapa Geológico do Estado do Paraná. Curitiba, DNPM/ MINEROPAR. (Escala 1:650.000).

BRANNER, B. (1919) Outlines of the geology of Brazil to accompany the geological map of Brazil. Geological Society of America Bulletin, v.30, n.2, p.189-338.

CAMPANHA, G.A.C. (1992) Tectônica proterozóica no alto e médio Vale do Ribeira, Estados de São Paulo e Paraná. São Paulo, 296p. (Tese - Doutorado) - Instituto de Geociências, Universidade de São Paulo.

CAMPANHA, G.A.C.; BISTRICHI, C.A.; ALMEIDA, M.A. (1987) Considerações sobre a organização litoestratigráfica da Faixa de Dobramentos Apiaí. In: SIMPÓSIO SULBRASILEIRO DE GEOLOGIA, 3., Curitiba, 1987. Atas. Curitiba, SBG, v. 2 , p. 725.742 .
CAMPOS NETO, M.C.; FIGUEIREDO, M.C.H. (1995) The Rio Doce orogeny, southeastern Brazil. Journal of South American Earth Sciences, v. 8, n.2, p.143-162.

CARVALHO, P.F. (1936) Geologia do Município de Curitiba. Boletim Divisão de Geologia e Mineralogia, v. 82, p. $1-37$

CORDANI, U.G. (1974) Comentários sobre as determinaçōes geocronológicas disponiveis nas Folhas Assunción e Curitiba. In: MONACO, O.A.; ZIR FILHO, J.A.; VALENTINE, N. (Eds.). Carta Geológica do Brasil ao Milionésimo, Folha AssunciónSG.21 e Curitiba- SG.22. Brasilia, DNPM, p.58-67.

CORDANI, U.G.; GIRARDI, V.A.V. (1967) Geologia da Folha de Morretes. Boletim da Universidade Federal do Paraná, Geologia, v.26, p. $1-40$.

CORDANI, U.G.; KAWASHITA, K. (1971) Estudo geocronológico pelo método $\mathrm{Rb}-\mathrm{Sr}$ de rochas graníticas intrusivas no Grupo Açungui. In: CONGRESSO BRASILEIRO DE GEOLOGIA, 25., São Paulo, 1971. Anais. São Paulo, SBG, v.1, p.105110.

DE LA ROCHE, H.; LETTERRIER, J.; GRANDCLAUDE, P.; MARCHAL, M. (1980) A classification of volcanic and plutonic rocks using R1R2 diagram and major-elements analyses - Its relationships with current nomenclature. Chemical Geology, v.29, n.112, p.183-210.

DE PAOLO, D.J. (1988) Neodymiun isotope geochemistry: an introduction. Berlin, Springer Verlag, 187p.

EVENSEN, N.H.; HAMIITON, P.J.; O'NIONS, R.K. (1978) Rare earth abundances in chondritic meteorite. Geochimica et Cosmochimica Acta, v.42, n.8, p.1119-1212.

FIORI, A.P. (1990) Tectônica e estratigrafia do Grupo Açungui a 
norte de Curitiba, São Paulo. São Paulo, 261p. (Tese - Livre Docência) - Instituto de Geociências, Universidade de São Paulo.

FIORI, A.P. (1992) Tectônica e estratigrafia do Grupo Açungui, PR. Boletim IG-USP, Série Científica, v.23, p.55-74.

FRAGOSO CESAR, A.R.S. (1980) O Cráton do Rio de La Plata e o Cinturão Dom Feliciano no Escudo Uruguaio-Sul Riograndense. In: CONGRESSO BRASILEIRO DE GEOLOGIA, 31., Camboriú, 1980. Anais. Camboriú, SBG, v.5, p.2879. 2892.

FRAGOSO CESAR, A.R.S. (1991) Tectônica de placas no Ciclo Brasiliano: as orogenias dos cinturōes Dom Feliciano e Ribeira no Rio Grande do Sul. São Paulo, 367p. (Tese - Doutorado) - Instituto de Geociências, Universidade de São Paulo.

FRAGOSO CESAR, A.R.S.; SOLIANI Jr., E. (1984) Compartimentação tectônica do Cráton Rio de La Plata. In: CONGRESSO BRASILEIRO DE GEOLOGIA, 33., Rio de Janeiro, 1984. Anais. Rio de Janeiro, SBG, v.5, p. 2426-2434.

FUCK, R.A (1966) Nota explicativa da Folha Geológica de Quero-Quero. Boletim da Universidade Federal do Paraná, Geologia, v.19, p.1-21.

FUCK, R.A. (1967a) Geologia da Folha de Piraquara. Curitiba, Comissão da Carta Geológica do Paraná, 37p. (Relatório inédito).

FUCK, R.A. (1967b) Geologia da Folha de São José dos Pinhais. Curitiba, Comissão da Carta Geológica do Paraná, 46p. (Relatório inédito).

FUCK, R.A. (1967c) Geologia da Folha Abapā. Boletim da Universidade Federal do Paraná, Geologia, v.25, p. $1-34$.

FUCK, R.A. (1967d) Geologia das
Folhas de Jaguaricatu e Socavão. Curitiba, Comissão da Carta Geológica do Paraná, 42p. (Relatório inédito).

FUCK, R.A. (1991) Aprovada nova escala de tempo para o pré-Cambriano. Revista Brasileira de Geociências, v.21, n.2, p.182-183.

FUCK, R.A.; TREIN, E.; MARINI, O.J. (1967a) Geologia e petrografia dos migmatitos do Paraná. Boletim Pa-ranaense de Geociências, n.2325, p. $5-41$.

FUCK, RA.; TREIN, E.; MURATORI, A.; RIVEREAU, I.C. (1969a) Mapa geológico preliminar do litoral, da Serra do Mar e parte do Primeiro Planalto do Estado do Paraná. Boletim Paranaense de Geociências, v. 27, p. $123-152$.

FUCK, R.A.; MURATORI, A.; TREIN, E. (1969b) Folha geológica de Barra de Ararapira. Curitiba, Comissão da Carta Geológica do Paraná. (Escala 1:70.000).

GIRARDI, V.A.V. (1969) Petrologia das rochas metamórficas da regiâo de Morretes-Antonina, PR. São Paulo, 131p. (Tese - Doutorado) Instituto de Geociências, Universidade de São Paulo.

GIRARDI, V.A.V. (1971) Os anfibolitos da região de Morretes - Antonina, PR. Revista Brasileira de Geociências, v. $1, \mathrm{n} .1$, p.43-65.

GIRARDI, V.A.V. (1976) Geologia e petrologia do Complexo Básico-U1trabásico de Piên, Paraná. Revista Brasileira de Geociências, v.6, n.2, p.109-124.

GIRARDI, V.A.V.; ULBRICH, H.H. G.J. (1978) Saphirine-orthopiroxene spinel occorrence in the Pien Area, Paraná, southern Brazil. Revista Brasileira de Geociências, v.8, n.4, p.284-293.

GIRARDI, V.A.V.; ULBRICH, H.H. G.J. (1980) Origin and evolution of the Piên Mafic-Ultramafic Complex, 
southern Brazil. Journal of Geology, v.88, n.3, p.251-269.

GIRARDI, V.A.V.; CORDANI, U.G.; CANDIDO, A.; MELFI, A.J.; KAWASHITA, K. (1974) Geocronologia do Complexo Básico-Ultrabásico pré-brasiliano de Piên, PR. In: CONGRESSO BRASILEIRO DE GEOLOGIA, 28., Porto Alegre, 1974. Resumo das Comunicações. Porto Alegre, SBG, p.532-533.

HALLINAN, S.E.; SHUKOWSKY, W.; MANTOVANI, M.S.M. (1993) Estruturação do embasamento precâmbrico da região sul do Brasil e Uruguai: novos modelos resultantes de densificação gravimétrica. In: SIMPOSIO INTERNACIONAL DEL NEOPROTEROZOICO - CAMBRICO DE LA CUENCA DEL PLATA, 1., La Paloma, 1993. Resumenes Extensos. La Paloma, DINAMIGE. v. 2, p. 31 .

HALLINAN, S.E.; MANTOVANI, M. S.M.; SHUKOWSKY, W.; BRAGGION Jr., I. (1993) Estrutura do Escudo Sul-Brasileiro: uma revisão através de dados gravimétricos e magnetométricos. Revista Brasileira de Geociências, v.23, n.

HARARA, M.O. (1996) Análise estrutural, petrológica e geocronológica dos litotipos da região de Piên (PR) e adjacências. São Paulo, 196p (Dissertação - Mestrado) - Instituto de Geociências, Universidade de São Paulo.

HARARA, M.O; BASEI, M.A.S.; SIGA Jr., O. (1994) Contribuição ao estudo geológico da região de Piên PR. In: CONGRESSO BRASILEIRO DE GEOLOGIA, 38., Camboriú, 1994. Boletim de Resumos Expandidos, Camboriú, SBG, v.1, p.64-65.

HASUI, Y.; CARNEIRO, C.D.R.; COIMBRA, A.M. (1975) The Ribeira Folded Belt. Revista Brasileira de Geociências, v.5, n.4, p.257266.
JUNG, J.; ROQUES, M. (1952) Introduction à l'etude zonéographique des formations cristallophyllienes. Bulletin de Service de la Carte Géologique de France, v.50, n.235, p.162.

KAUL, P.F.T. (1979) Pré-Cambriano e Eopaleozóico do nordeste de Santa Catarina e leste do Paraná: reavaliação de dados e correlações com a África. In: SIMPÓSIO REGIONAL DE GEOLOGIA, 2., Rio Claro, 1979. Atas. Rio Claro, SBG, v.1, p. $1-15$.

KAUL, P.F.T. (1980) O Cráton de Luis Alves. In: CONGRESSO BRASILEIRO DE GEOLOGIA, 31., Camboriú, 1980. Anais. Camboriú, SBG, v.5, p. 2677-2683.

KAUL, P.F.T.; TEIXEIRA, W. (1982) Archean and early proterozoic complexes of Santa Catarina, Paraná and São Paulo states, south-southeaster, Brazil: an outline of their geological evolution. Revista Brasileira de Geociências, v.12, n.1-3, p.172-182.

KAUL, P.F.T.; COUTINHO, J.B.L.; ISSLER, R.S.; BONOW, C.W.; MOREIRA, M.L.O; MARIMON, M.P.C.; MOREIRA, H.L.; SILVA, R.N.; MARINHO, D.; TEIXEIRA, W. (no prelo) Folhas SG-22/23/21 Curitiba/Iguape/Assunción. Levantamento de Recursos Naturais, IBGE

KAWASHITA, K.; SATO, K.; DIAS, M.; TASSINARI, C.C.G. (1991) Metodologia Sm/Nd no IG-USP: testes e resultados preliminares. In: $\mathrm{CON}$ GRESSO BRASILEIRO DE GEOQUíMICA, 3., São Paulo, 1991. Boletim de Resumos. São Paulo, SBGq/Sociedade Geológica de Portugal, v.2, p.442-446.

LOPES, J.A.U. (1966) Nota explicativa da folha geológica de Curitiba. Boletim da Universidade Federal do Paraná, Geologia, n.18, p.1-20.

LOPES, O.F. (1987) Zoneamento meta- 
mórfico da Formação Rio das Cobras do pré-Cambriano do estado do Paraná. In: SIMPÓSIO SUL BRASILEIRO DE GEOLOGIA, 3, Curitiba, 1987. Atas. Curitiba, SBG, v.1, p.303-312.

MAACK, R. (1953) Mapa geológico do Estado do Paraná. Curitiba, IBPT. (Escala 1:750.000).

MAACK, R. (1961) Sobre a ocorrência de granitos alcalinos no Estado do Paraná e sua porção dentro das fases orogenéticas algonquianas. Boletim da Universidade Federal do Paraná, Geologia, v.4, p.1-52.

MACHIAVELLI, A. (1991) Os granitóides deformados da Região de Piên (PR): um provável Arco Magmático do Proterozóico Superior. São Paulo, 89p. (Dissertaçăo - Mestrado) - Instituto de Geociências, Universidade de São Paulo.

MACHIAVELLI, A.; BASEI, M.A.S.; SIGA Jr., O. (1991) Geoquímica e geocronologia dos granitóides deformados da região de Piên (PR). Provável arco magmático do Proterozóico Superior. In: CONGRESSO BRASILEIRO DE GEOQUIIMICA, 3., São Paulo, 1991. Resumos. São Paulo, SBGq, v.1, p.249-253.

MACHIAVELLI, A.; BASEI, M.A.S.; SIGA Jr., O. (1993) Suíte Granitica Rio Piên: um arco magmático do Proterozóico Superior na Microplaca Curitiba. Geochimica Brasiliensis, v.7, n.2, p.113-129.

MANTOVANI, M.S.M.; HAWKESWORTH, C.J.; BASEI, M.A.S. (1987) $\mathrm{Nd}$ and $\mathrm{Pb}$ isotope studies bearing on the crustal evolution of Southeastern Brazil. Revista Brasileira de Geociências, v.17, n.3, p.263-268.

MANTOVANI, M.S.M; SHUKOWSKY, W.; BASEI, M.A.S.; VASCONCELOS, A.C.B.C. (1989) Modelo gravimétrico das principais descontinuidades crustais nos terrenos pré-
Cambrianos dos Estados do Paraná e Santa Catarina. Revista Brasileira de Geociências, v.19, n.3, p.367374.

MARINI, O.J. (1967) Geologia da Folha de Araucária. Curitiba, Comissão da Carta Geológica do Paraná, 24 p. (Relatório inédito).

MURATORI, A. (1966) Nota explicativa da Folha geológica de Campo Largo. Boletim da Universidade Federal do Paraná, Geologia, n.21, p.133.

OLIVEIRA, A.I.; LEONARDOS, O.M. (1943) Geologia do Brasil. Rio de Janeiro, Ministério de Agricultura. 813 p. (Série Didática, n.2).

OLIVEIRA, E.P. (1925) Mapa geológico do Estado do Paraná. Serviço Geológico e Mineralógico do Brasil. (Escala 1:1.000.000).

OLIVEIRA, E.P. (1927) Geologia e recursos minerais do Estado do Paraná. Boletim do Serviço Geológico e Mineralógico do Brasil, Monografias, n.6, p.1-172.

PERROTTA, M.M.; MORAIS, S.M. (1992) A suíte mangerito-norítica, Curitiba. In: CONGRESSO BRASILEIRO DE GEOLOGIA, 37., São Paulo, 1992. Boletim de Resumos Expandidos. São Paulo, SBG, v.1, p.417.

PIMENTEL, M.M.; CHARNLEY, N. (1991) Intracrustal REE fractionation and implication for Sm-Nd model age calculations in late stage granitic rocks: an example from central Brasil. Chemical Geology, v.186, n. 2, p. 123-138.

REIS NETO, J.M. (1994) Faixa Itaiacoca: registro de uma colisão entre dois blocos continentais no neoproterozóico. São Paulo, 253p. (Tese Doutorado), Instituto de Geociências, Universidade de São Paulo.

REIS NETO, J.M.; SIGA Jr., O.; BASEI, M.A.S.; CASTRO, N.A. (1993) Complexo Básico e Ultrabá- 
sico de Piên: uma revisão estratigráfica. In: SIMPÓSIO SUL-BRASILEIRO DE GEOLOGIA, 5., Curitiba, 1993. Boletim de Resumos. Curitiba, SBG, p.43.

RIBAS, S.M. (1993) O complexo máfico-ultramáfico de Tijucas do Sul, correlação com o Complexo de Piên, PR e consideraçōes metalogenéticas. Campinas, 130p. (Dissertação - Mestrado) - Instituto de Geociências, Universidade de Campinas.

RUBERTI, E. (1977) Mineralogia e química dos anfibolitos da região de Morretes-Antonina, Paraná. São Paulo, 86p. (Dissertação - Mestrado) - Instituto de Geociências, Universidade de São Paulo.

RUBERTI, E.; GOMES, C.B. (1977) Mineralogia e química dos anfibolitos da região de Morretes-Antonina, PR. Revista Brasileira de Geociências, v.7, n.4, p.325-348.

SATO, K.; TASSINARI, C.C.G.; KAWASHITA, K.; PETRONILHO, L. (1995) Método geocronológico SmNd no IG-USP e suas aplicaçōes. Anais da Academia Brasileira de Ciências, v.67, n.3, p.313-336.

SIGA Jr., O. (1995) Domínios tectônicos do sudeste do Paraná e nordeste de Santa Catarina: geocronologia e evolução crustal. São Paulo, 212p. (Tese - Doutorado) - Instituto de Geociências, Universidade de São Paulo.

SIGA Jr., O.; BÁSEI, M.A.S.; MACHIAVELLI, A. (1993) Modelagem geocronológica do setor NE de Santa Catarina e SE do Paraná, Brasil. In: SIMPOSIO INTERNACIONAL DEL NEOPROTEROZOICO-CAMBRICO DE LA CUENCA DEL PLATA, 1., La Paloma, 1993. Resumenes Extensos. La Paloma, DINAMIGE. v. 2, p. 30 .

SIGA Jr., O; BASEI, M.A.S.; MACHIAVELLI, A. (1990a) Evoluçăo geotectônica do Maciço de Joinville,
PR e SC. In: JORNADAS CIENTÍFICAS DO INSTITUTO DE GEOCIÊNCLAS. São Paulo, 1990. Boletim Especial Trabalhos Apresentados. São Paulo, Instituto de Geociências-USP. p.116-118.

SIGA Jr., O.; BASEI, M.A.S.; KAWASHITA, K. (1990b) Perfil Térmico $\mathrm{K}-\mathrm{Ar}$ através do Maciço de Joinville (PR e SC) e do Cinturão Dom Feliciano (SC). Implicaçōes tectônicas. In: CONGRESSO BRASILEIRO DE GEOLOGIA, 36., Natal, 1990. Anais. Natal, SBG, v.6, p. 2773-2785.

SIGA Jr., O; BASEI, M.A.S; MACHIAVELLI, A. (1993) Evolução geotectônica da porção NE de Santa Catarina e SE do Paraná, com base em interpretações geocronológicas. Revista Brasileira de Geociências, v.23, n.3, p.215-223.

SIGA Jr., O.; BASEI, M.A.S.; REIS NETO, J.M; BUBA, R.M. (1994) Maciços Graníticos da porção sudeste do Paraná e nordeste de Santa Catarina: geocronologia e implicações tectônicas. In: CONGRESSO BRASILEIRO DE GEOLOGIA, 38. Camboriú, 1994. Boletim de Resumos Expandidos. Camboriú, SBG, v. 2, p. 400-401.

SOARES, P.C. (1987) Seqüências tecto-sedimentares e tectônica deformadora no centro-oeste do Escudo Paranaense. In: SIMPÓSIO SUL-BRASILEIRO DE GEOLOGIA, 3., Curitiba, 1987. Atas. Curitiba, SBG, v.2, p. 743-772.

SOARES, P.C. (1988) Tectônica colisional em torno do Bloco Paraná, Brasil. In: CONGRESSO LATINOAMERICANO DE GEOLOGIA, 7. Belém, 1988. Anais. Belém, SBG, v.1, p.63-79.

SOLIANI Jr., E. (1986) Os dados geocronológicos do Escudo Sul Rio Grandense e suas implicaçōes de ordem geotectônica. São Paulo, 
239p. (Tese - Doutorado) - Instituto de Geociências, Universidade de São Paulo.

SOLIANI Jr., E.; FRAGOSO CESAR, A.R.S.; TELXEIRA, W.; KAWASHITA, K. (1984) Panorama geocronológico da porção meridional do Escudo Atlântico. In: CONGRESSO BRASILEIRO DE GEOLOGIA, 33 , Rio de Janeiro, 1984. Anais. Rio de Janeiro, SBG, v.5, p.2435-2449.

STEIGER, R.H.; JÂEGER, E. (1978) Subcomission on geochronology: convention on the use of decay constants in geochronology and cosmochronology. Studies in Geology, v.6, p.67-71.

TEIXEIRA, W. (1979) Avaliação preliminar do acervo geocronológico das folhas Assunción, Curitiba e Iguape. Rio de Janeiro, DNPM/ MME, 30p. (Relatório Interno).
TELXEIRA, W. (1982) Folhas Assunción, Curitiba e Iguape. Consideraçōes sobre os dados radiométricos e evoluçâo geocronológica. Rio de Janeiro, DNPM/MME, 38p. (Relatório Interno).

TREIN, E. (1967) Geologia da Folha de Contenda, PR. Boletim da Universidade Federal do Paraná, Geologia, n.27, p.1-39.

TREIN, E.; FUCK, R.A.; MURATORI, A. (1969) Folha geológiea de Tijucas do Sul. Curitiba, Comissão da Carta Geológica do Paraná. (Escala 1:70.000).

TREN, E.; MURATORI, A.; BASUMALLICK, S.; BERTOLDO, A.L. (1970) Folha geológica de Antonina. Curitiba, Comissâo da Carta Geológica do Paraná. (Escala 1:70.000). 


\section{APÊNDICE}

Tabela 1 - Dados radiométricos K-Ar.

\begin{tabular}{|c|c|c|c|c|c|c|c|c|c|c|}
\hline SPK & $N^{\circ}$ Campo & Litologia & Material & DOMINI & $\begin{array}{c}\mathrm{Ar}^{40} \mathrm{Rad} \\
10^{-6} \\
\text { IO CURITIBA }\end{array}$ & $\begin{array}{l}\% A r \\
\text { atm }\end{array}$ & Idade & Erro & Localizaçäo & Ref \\
\hline 627 & MJ-138 & GNS & BIO & 5.806 & 164.1 & 6.1 & 61 & 1 & N Mandirituba & NT \\
\hline 627 & MJ-138 & GNS & ANF & 1.808 & 65.3 & 1.3 & 75 & 2 & $\mathrm{~N} \mathrm{Mr}$ & NT \\
\hline 625 & MJ-23 - 137 & GNS & ANF & 0.143 & 3.9 & 80. & 60 & 7 & N Mandirituba & NT \\
\hline 627 & MI-123.A & MIG & $\mathrm{BIO}$ & 5.064 & 133.7 & 3.9 & 57 & I & S Mandirituba & NT \\
\hline 625 & MI-9 & MIG & BIO & 7.217 & 194.6 & 23.0 & 58 & 2 & Atuba & NT \\
\hline 669 & $\mathrm{MJ}-316.1$ & ANF & ANF & 0.326 & 8.4 & 41.3 & 56 & 3 & Quitandinha & NT \\
\hline 665 & $\mathrm{MJ}-3$ & MIG & ANF & 1.806 & 49.2 & 20.3 & 59 & 1 & Quitan & NT \\
\hline 665 & MJ-310.B & GNS & $\mathrm{BIO}$ & 5.787 & 149.3 & 7.7 & 56 & 1 & W Mandirituba & NT \\
\hline 693 & MJ-378 & GNS & PLG & 4.043 & 95.1 & 22.9 & 52 & 1 & SE Curitiba & NT \\
\hline 709 & MJ-5 & GNS & BIO & 5.427 & 156.1 & 7.3 & 62 & 4 & Q. Barras & NT \\
\hline 708 & MJ -550 & GNS & $\mathrm{ANF}$ & 1.425 & 42.0 & 8. & 63 & 5 & Q. Barras & NT \\
\hline 7190 & MJ-638.A & GNS & ANF & 2.256 & 62.4 & 10.6 & 60 & 2 & BR-116 & NT \\
\hline 7189 & MJ-638A & ONS & BIO & 6.785 & 190.4 & 5.9 & 60 & & BR-116 & NT \\
\hline 7167 & MJ $636 \mathrm{~A}$ & GNS & ANF & 1.084 & 33.1 & 22.8 & 65 & 1 & BR-116 & NT \\
\hline 7162 & MJ-639.1 & GNS & BIO & 5.848 & 161.1 & 6.7 & 59 & 1 & BR-116 & NT \\
\hline 7165 & MM-89D & $\mathrm{CHQ}$ & ANF & 1.188 & 136.7 & 6.4 & 175 & 7 & W Curitiba & NI* \\
\hline
\end{tabular}

Tabela 2 - Dados radiométricos Rb-Sr.

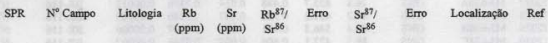

\section{DOMINIO CURTIBA}

\begin{tabular}{|c|c|c|c|c|c|c|c|c|c|}
\hline 9384 & -96.1 & MIG & 19.8 & 182.9 & 0.315 & 0.003 & 0.7207 & 0.0000 & Atuba \\
\hline 9385 & $4 J-96.2$ & MIG & 29.6 & 153.8 & 0.557 & 0.004 & 0.7180 & 0,0000 & \\
\hline 11124 & MJ-96.3 & MIG & 115.0 & 264.0 & 1.263 & 0.036 & 0.7271 & 0.0000 & ba \\
\hline 11132 & MU-96.3BIO & MIG & 625.0 & 46.0 & 40.806 & 1.112 & 1.0903 & 0.0001 & \\
\hline 1113 & MJ-96.3ANF & MIG & 179.0 & 83.0 & 6.279 & 0.176 & 0.7677 & 0.0000 & \\
\hline 9387 & MJ-96.4 & MIG & 111.2 & 600.0 & 0.537 & 0.015 & 0.7215 & 0.0000 & \\
\hline 10018 & 1]-96.5 & MaG & 126.8 & 763,0 & 0.481 & 0.013 & 0.7187 & 0.0000 & \\
\hline 9388 & $\mathrm{MJ}-$ & MIG & 76.7 & 264.7 & 0.840 & 0.024 & 0.7242 & 0.0000 & \\
\hline 9936 & MJ & MIG & 102.1 & 650.0 & 0.455 & 0.002 & & 0.0002 & \\
\hline 9390 & M]- & MIG & 113.7 & 592.5 & 0.556 & & & & \\
\hline 9391 & M- & GRN & 245.7 & 423.1 & 1.687 & & & & \\
\hline 9392 & MJ- & GRN & 162.4 & 336.2 & 1.403 & 0.040 & & 0.0000 & \\
\hline 10762 & MJ- & MES & 43.5 & 685.5 & 0.184 & 0.0 & & 0.0002 & tinha \\
\hline 10763 & MJ- & MES & 51.2 & 756.0 & 0.196 & & & & linha \\
\hline 10764 & $\mathrm{MJ}$ & LEU & 53.5 & 605.5 & 0.256 & 0.0 & & 0.0 & linha \\
\hline 10765 & MJ- & MES & 73.5 & 623.5 & 0.341 & & & 0.0 & Jinha \\
\hline 10766 & MJ- & LEU & 78.5 & 536.0 & 0.424 & & 0.7162 & 0.00004 & Quit: \\
\hline 10916 & $\mathrm{M}$ & LEU & 63.0 & 700.0 & 0.261 & 0.007 & 0.7150 & 0.00006 & Quitandinha \\
\hline 10917 & $\mathrm{MJ}-3$ & LEU & 37.0 & 654.0 & 0.164 & 0.005 & 0.7113 & 0.00006 & Quitandinha \\
\hline 10918 & $\mathrm{MJ}-315 . \mathrm{G}$ & LEU & 73.0 & 562.0 & 0.376 & 0.011 & 0.7160 & 0.00007 & Quitandinha \\
\hline 10768 & $\mathrm{MJ}-316 . \mathrm{C}$ & MES & 66.5 & 430.0 & 0.448 & 0.013 & 0.7170 & 0.00004 & Quitandinha \\
\hline 10769 & MJ-316.I & LEU & 65.5 & 483.0 & 0.393 & 0.011 & 0.7164 & 0.00004 & Quitandinha \\
\hline 10770 & $\mathrm{MJ}-316 \mathrm{~J}$ & LEU & 44.5 & 481.0 & 0.268 & 0.080 & 0.7143 & 0.00004 & Quitandinha \\
\hline
\end{tabular}


Tabela 2 (conclusão).

\begin{tabular}{|c|c|c|c|c|c|c|c|c|c|}
\hline SPR & $\mathrm{N}^{\circ}$ Campo & Litologia & $\begin{array}{c}\mathrm{Rb} \\
(\mathrm{ppm})\end{array}$ & $\begin{array}{c}\text { Sr } \\
(\mathrm{ppm})\end{array}$ & $\begin{array}{l}\mathrm{Rb}^{87} / \\
\mathrm{Si}^{86}\end{array}$ & Erro & $\begin{array}{l}\mathrm{Sr}^{\mathrm{B} 7} \mathrm{j} \\
\mathrm{Sr}^{85}\end{array}$ & Erro & alização \\
\hline 771 & MJ-316.L & LEU & 31.5 & 490.0 & 0.186 & 0.005 & 0.7151 & 0.00004 & Quitandinha \\
\hline 0919 & $\mathrm{MJ}-316 . \mathrm{E}$ & LEU & 32.0 & 294.5 & 0.315 & 0.009 & 0.7161 & 0.00009 & Quitandinha \\
\hline 10920 & $\mathrm{M}-316 . \mathrm{F}$ & MES & 47.0 & 336.5 & 0.405 & 0.011 & 0.7151 & 0.00009 & Quitandinha \\
\hline 10921 & M-316.M & LEU & 64.0 & 433.5 & 0.428 & 0.012 & 0.7156 & 0.00011 & Quitandinha \\
\hline 1378 & MJ-316.B & MES & 12.5 & 205.1 & 0.177 & 0.003 & 0.7120 & 0.00006 & Quitandinha \\
\hline 045 & MJ-25.3 & NOR & 87.6 & 288.5 & 0.881 & 0.025 & 0.7333 & 0.00008 & N Curitibs \\
\hline 1046 & MJ-25.5 & NOR & 94.7 & 291.8 & 0.942 & 0.027 & 0.7343 & 0.00004 & N Curitibe \\
\hline 047 & MJ-25.9 & NOR & 97.1 & 311.0 & 0.906 & 0.026 & 0.7332 & 0.00007 & N Curitiba \\
\hline 048 & MJ-2 & NOR & 76.2 & 299.8 & 0.737 & 0.021 & 0.7311 & 0.00006 & N Curitiba \\
\hline 049 & MJ & NOR & 62.8 & 282.9 & 0.644 & 0.018 & 0.7278 & 0.00008 & N Currtiba \\
\hline 1125 & MJ-25.1 & NOR & 108.0 & 268.0 & 1.170 & 0.033 & 0.7406 & 0.00008 & $\mathrm{NC}$ \\
\hline 1126 & $\mathrm{M}-25.2$ & NOR & 124.0 & 264.0 & 1.365 & 0.038 & 0.7465 & 0.00007 & \\
\hline 11127 & MJ-25.7 & NOR & 90.0 & 266.0 & 0.982 & 0.028 & 0.7339 & 0.00009 & N Curitiba \\
\hline 11128 & MJ-25.10 & NOR & 80.0 & 296.0 & 0.784 & 0.022 & 0.7331 & 0.00006 & $\mathrm{NC}$ \\
\hline 11129 & MJ -25.12 & NOR & 87.0 & 282.0 & 0.895 & 0.025 & 0.7334 & 0.00007 & $\mathrm{NC}$ \\
\hline UK & MJ -25.3 & NOR & 88.0 & 288.0 & 0.887 & 0.025 & 0.7335 & 0.00002 & $\mathrm{NC}$ \\
\hline 11929 & MM-87A & NOR & 99.3 & 358.7 & 0.803 & 0.023 & 0.7286 & 0.00007 & W \\
\hline 11930 & $\mathrm{MM}$ & NOR & 104.8 & 354.9 & 0.856 & 0.024 & 0.7275 & 0.00018 & W C \\
\hline 11931 & $\mathrm{MM}$ & NOR & 44.2 & 420.0 & 0.305 & 0.009 & 0.7188 & 0.00 & W \\
\hline 11932 & $\mathrm{MI}$ & N & 88 & 362.7 & 0.7 & 0.020 & 223 & 108 & w \\
\hline 11933 & $\mathrm{MM}-$ & NOR & 72.8 & 415.4 & 0.5 & 0.014 & & 09 & \\
\hline 11934. & $1-95 \mathrm{~A}$ & NOR & 87.8 & 246.7 & 1.0 & 0.029 & 0.7 & & \\
\hline 11935 & M & NOR & 92.3 & 229.3 & 1.1 & 0.033 & 0.7 & & \\
\hline 12258 & $\mathrm{MM}-89 \mathrm{~A}$ & NOR & 67.0 & 394.0 & 0.492 & 0.020 & & & \\
\hline 12024 & MJ-5 & GNS & 73.3 & 609.9 & 0.3 & 0.001 & 0.7151 & & \\
\hline 12025 & $\mathrm{MJ}-6$ & GNS & 14.5 & 489.0 & 0.086 & 0.001 & & & $\mathrm{BR}$ \\
\hline 12026 & MJ-6 & GNS & 87.9 & 1558.9 & 0.163 & 0.002 & 0.7078 & 0.0 & \\
\hline 12027 & $\mathrm{MJ}$ & GNS & 76.8 & 455.7 & 0.488 & 0.014 & 0.7196 & & B \\
\hline 12028 & MJ-6 & GNS & 81.2 & 451.2 & 0.521 & 0.007 & 0.7246 & & $\mathrm{BP}$ \\
\hline 12029 & MJ-6 & GNS & 81.4 & 546.5 & 0.4 & 0.006 & 207 & & BF \\
\hline 12030 & MJ-638C & GNS & 89.3 & 427.1 & 0.606 & 0.009 & 0.7248 & & $\mathrm{BR}$ \\
\hline 11380 & MJ-138 & GNS & 77.0 & 656.8 & 0.339 & 0.010 & 0.7137 & 09 & N Mandirituba \\
\hline 11379 & $M J-23=137$ & GNS & 2.3 & 198.7 & 0.034 & 0.000 & 0.7037 & 0.00005 & N Mandirituba \\
\hline UK & MJ-137 & GNS & 1.0 & 197.0 & 0.015 & 0.001 & 0.7038 & 0.00001 & $\mathrm{~N}$ Mandirituba \\
\hline UK & MJ-123.A & GNS & 88.0 & 882.0 & 0.289 & 0.008 & 0.7089 & 0.00002 & S Mandirituba \\
\hline 11821 & M. $-462 D$ & $\mathrm{MOB}(\mathrm{BIO})$ & 446.2 & 17.1 & 80.278 & 1.250 & 1.3783 & 0.00011 & Quitandinha \\
\hline 11724 & MD $-462 \mathrm{D}$ & MOB(K-F) & 173.2 & 559.4 & 0.897 & 0.025 & 0.7223 & 0.00010 & Quitandinha \\
\hline 11726 & MJ-462D & MOB(ANF) & 67.8 & 42.3 & 4.657 & 0.131 & 0.7466 & 0.00006 & Quitandinha \\
\hline 10820 & MJ-292.C & GNS & 98.0 & 631.0 & 0.450 & 0.013 & 0.7153 & 0.00006 & \\
\hline 10823 & M]-294.1 & GNS & 32.5 & 618.0 & 0.152 & 0.004 & 0.7061 & 0.00005 & \\
\hline UK & MJ-296 & GNS & 28.0 & 560.0 & 0.145 & 0.004 & 0.7060 & 0.00002 & Graciosa \\
\hline
\end{tabular}

- Afloramento localizado na Rodovia BR-116, a NE da área investigada.

Tabela 3 - Dados radiométricos U-Pb - zircões.

Fracalo Concentraçôes $N^{\circ}$ Litologia Magnética U Pb Campo (ppm) (ppm)
Razóes Medidas Razóes $\mathrm{U} / \mathrm{Pb}$ Idade $\mathrm{Pb}^{207 /} \mathrm{Pb}^{208} j \mathrm{~Pb}^{206 j} \mathrm{~Pb}^{207 /}$ 207. Ref $\begin{array}{llllll}\mathrm{Pb}^{206} & \mathrm{~Pb}^{206} & \mathrm{~Pb}^{206} & \mathrm{U}^{235} & \mathrm{U}^{735} & 20\end{array}$

\section{DOMINIO CURTTIBA}

$\begin{array}{llllllllllll}\text { USA M- NOR } & \mathrm{NM}(-2) & 98.0 & 42.0 & 0.00031 & 0.12933 & 0.16190 & 0.37820 & 6.743 & 208 & \text { NT }\end{array}$ $\begin{array}{llllllllllll}25.11 & M(0) & 85.0 & 36.0 & 0.00037 & 0.13002 & 0.17150 & 0.37530 & 6.728 & 209 & \text { NT }\end{array}$ $\begin{array}{lllllllllll}M(2) & 101.0 & 46.0 & 0.00205 & 0.12986 & 0.15600 & 0.37470 & 6.709 & 209 & \text { NT }\end{array}$ 


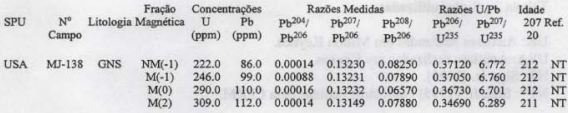

Tabela 4 - Dados radiométricos Sm-Nd em rocha total.

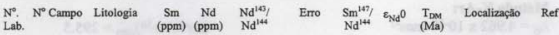

\section{DOMINIO CURITIBA}

$\begin{array}{llllllllllll}\text { UK } & \text { MJ-25.3 } & \text { NOR } & 6.86 & 38.4 & 0.51110 & 0.00002 & 0.108 & -29 . & 2822 & \text { N Curitiba } & \text { NT } \\ \text { UK } & \text { MJ-96.3 } & \text { MIG } & 6.29 & 33.1 & 0.51127 & 0.00001 & 0.115 & -26 . & 2755 & \text { Atuba } & \text { NT } \\ \text { UK } & \text { MJ-138 } & \text { GNS } & 4.53 & 24.1 & 0.51145 & 0.00001 & 0.114 & -23 . & 2426 & \text { N Mandirituba } & \text { NT } \\ \text { UK } & \text { MJ-123.A } & \text { MIG(MOB) } & 7.65 & 59.2 & 0.51102 & 0.00002 & 0.078 & -31 . & 2275 & \text { S Mandirituba } & \text { NT } \\ \text { 289 } & \text { MJ-316.F } & \text { MIG(MES) } & 6.20 & 24.0 & 0.51190 & 0.00002 & 0.156 & -14 . & 2808 \text { Quitandinha } & \text { NT }\end{array}$

Tabela 5 - Dados radiométricos Sm-Nd em minerais.

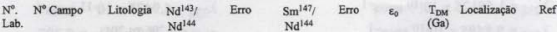

\section{DOMINIO CURITIBA}

$\begin{array}{lllllllllll}\text { UK } & \text { MJ-137-RTO } & \text { GNS } & 0.512474 & 0.000016 & 0.15415 & 0.005 & -3.2 & 1.44 & \text { NMandirituba NT } \\ \text { UK } & \text { MJ-137-GRA } & \text { GNS } & 0.513846 & 0.000010 & 0.50610 & 0.016 & 23.5 & 0.39 & \text { N Mandirituba } & \text { NT } \\ \text { UK } & \text { M-137-ANF } & \text { GNS } & 0.512573 & 0.000006 & 0.16830 & 0.005 & -1.2 & 1.54 & \text { N Mandirituba NT } \\ \text { UK } & \text { MJ-137-PLG } & \text { GNS } & 0.512377 & 0.000008 & 0.10796 & 0.003 & -5.0 & 0.99 & \text { NMandirituba NT }\end{array}$

Tabela 6 - Denominações utilizadas.

ANF - Anfibolito
CHQ - Charnoquito
GRN - Granito
GNS - Gnaisse
LEU - Leucossoma (migmatito)
MES - Mesossoma (migmatito)
MOB - Mobilizado (qzo-feldspático)
MIG - Migmatito
NOR - Norito

\section{MINERAIS}

ANF - Anfibólio

BIO - Biotita

KF - K-Feldspato

PLG - Plagioclásio

RTO - Rocha Total 
Tabela 7 - Siglas utilizadas.

UK: Análises realizadas em Milton Keynes.

USA: Análises realizadas em Kansas.

NT: Siga Jr. (1995).

NT*: Siga Jr. (1995) - amostras cedidas pela CPRM.

Tabela 8 - Constantes utilizadas.

\section{Método K-Ar:}

$\lambda_{\beta}=4.962 \times 10^{-10}$ anos $^{-1}$

$\mathrm{K}^{40}$ total $=0.581 \times 10^{-10} \mathrm{anos}^{-1}$

$$
\begin{aligned}
& \left(\mathrm{Ar}^{40 / \mathrm{Ar}^{36}}\right)_{\text {atm }}=295.5 \\
& \mathrm{~K}^{40}=0.01167 \% \mathrm{~K}_{\mathrm{t}}
\end{aligned}
$$

\section{Método Rb-Sr}

$\lambda_{\mathrm{Rb}}=1.42 \times 10^{-11}$ anos $^{-1}$

$\left(\mathrm{Rb}^{85} / \mathrm{Rb}^{87}\right)_{\mathrm{N}}=2.59265$

$\left(\mathrm{Sr}^{86} / \mathrm{Sr}^{88}\right)_{\mathrm{N}}=0.1194$

\section{Método U-Pb / Pb-Pb}

$\lambda_{238}=1.55125 \times 10^{-10}$ anos $^{-1}$

$$
\begin{aligned}
& \lambda_{232}=4.9475 \times 10^{-11} \text { anos }^{-1} \\
& a_{0}=\left(\mathrm{Pb}^{206 / \mathrm{Pb}^{204}}\right)_{\mathrm{T}}=9.307 \\
& \mathrm{~b}_{0}=\left(\mathrm{Pb}^{207} / \mathrm{Pb}^{204}\right)_{\mathrm{T}}=10.294
\end{aligned}
$$$$
\lambda_{235}=9.8485 \times 10^{-10} \text { anos }^{-1}
$$

$\mathrm{U}^{238} / \mathrm{U}^{235}=137.88$

\section{Método Sm-Nd}

$\lambda_{147}=6.54 \times 10^{-12}$ anos $^{-1}$

$\left(\mathrm{Nd}^{143} / \mathrm{Nd}^{144}\right)_{0} \mathrm{CHUR}=0.512638$

$\mathrm{DM}=0.513114$

$\left(\mathrm{Sm}^{147} / \mathrm{Nd}^{144}\right)_{\circ} \mathrm{CHUR}=0.1967$

$\mathrm{DM}=0.222$

O.Siga Jr. - Instituto de Geociências, Universidade de São Paulo, Caixa Postal 11.348, CEP 05422-970, São Paulo, SP, Brasil. 